\title{
Biogeographic patterns in small ground-dwelling vertebrates of the Western Australian wheatbelt
}

\author{
Allan H. Burbidge', J.K. Rolfe', N.L. McKenzie ${ }^{1}$ and J.D. Roberts ${ }^{2}$ \\ 'Department of Conservation and Land Management, Science Division \\ PO Box 51 Wanneroo, Western Australia 6946, Australia \\ School of Animal Biology M092, University of Western Australia, 35 Stirling Highway, \\ Crawley, Western Australia 6009. Australia
}

\begin{abstract}
Ground-dwelling frogs, reptiles and small mammals were sampled at 252 quadrats chosen to represent the geographical extent and diversity of uncleared terrestrial environments across the Western Australian wheatbelt. These sites were not overtly affected by secondary salinisation, but did include sites that were 'naturally' saline. We recorded a total of 144 species from 74 genera and 15 tamilies. There was an average of 10.4 species per quad rat with a range from one to 19 . Vertebrate species richness was highest on dissection valley floors and sandy depositional surfaces of the 'old plateau' but lowest on saltflats. Total species richness was positively correlated with high levels of sand, with low levels of soil nutrients and with good soil drainage. When frogs, reptiles and mammals were considered separately, temperature and rainfall attributes were also shown to exhibit correlations with species richness. Patterns in species composition could be explained in terms of climatic and substrate variables, including salinity. Two distinct faunas were identified - one concentrated in the semi-arid northern and inland parts of the study area, and one concentrated in the more mesic south and south-east. Further patterning could be discerned within this dichotomy, including the existence of a small group of species that are associated with saline areas. Correlations between climatic and substrate variables could be discerned even at very low levels in the classification analysis, suggesting strong deterministic patterns in vertebrate species composition across the study area. Integrated management programs over entire catchments will be necessary in order to maintain conservation values, but there is doubt that the impacts of salinisation and fragmentation can be mitigated quickly enough to allow the small, ground-dwelling vertebrate fauna to withstand the effects of these processes in the Western Australian wheatbelt.
\end{abstract}

\section{INTRODUCTION}

Much of the native vegetation in south-western Australia has been removed in the pursuit of agricultural enterprises, just as in many other parts of temperate Australia. In parts of the Western Australian wheatbelt more than $95 \%$ of native vegetation has been replaced by annual cereals or herbaceous pasture plants. Removal of native vegetation in this area began before 1900 (Saunders et al., 1985) and has continued to the present time. Unfortunately, this has occurred in an area that is susceptible to salinisation. Not surprisingly, there has also been preferential clearing of the soils more suited for agriculture, which are primarily on the valley floors and lower slopes. Such areas are less well represented in the reserve system than, for example, areas around rock outcrops or breakaways.

In southwestern Australia the regolith, because of its antiquity, contains a store of salt derived from rainfall and dry fallout, and consisting mainly of sodium chloride (Hingston and Gailitis, 1976). As a result of this, together with the subdued topography and hot climate, there are parts of the landscape that are 'naturally' saline (Salama, 1994). In a terrestrial context, salinisation is a pedogenic process that concentrates salts at or near the soil surface when evapo-transpiration greatly exceeds water inputs from precipitation. This can occur as a result of natural physical or chemical processes or as a result of human activities, such as clearance of native vegetation, in which case it is termed secondary salinisation (Chassemi of al., 1995). In south-western Australia, as in some other agricultural areas in Australia and elsewhere in the world, replacement of native woody perennial plants with short lived herbaceous plants has resulted in major alterations to the hydrological cycle, with rising water tables bringing a significant salt load near the land surface. This secondary 
salinisation has obvious deleterious consequences, not only for agricultural production, water quality and infrastructure maintenance, but also for conservation of native plant and animal communities in the remaining remnants of the original vegetation (George et al., 1995; ANZECC, 2001; Cramer and Hobbs, 2002).

The link between removal of woody plants and increasing salinity levels in groundwater has been recognised in south-western Australia since the early 1900s (Mann, 1907; Wood, 1924) and is now relatively well understood (e.g. Clarke et al., 2002). Clearing of native vegetation has continued, however, and nearly two million hectares (about $10 \%$ of the wheatbelt) are now affected by salinisation, with a high likelihood that the extent could double within the next 20 years (Ferdowsian et al., 1996). The process of secondary salinisation is likely to pose a significant threat to many native plants and animals, through its impact on habitat structure and quality. However, even though awareness of the 'salinity crisis' is now widespread (Beresford et al., 2001; Sexton, 2003) little is known about the effects of salinisation on the native terrestrial biota, particularly on native animals (Cramer and Hobbs, 2002; Briggs and Taws, 2003).

In such an environment, an important first step in conservation management is to document the geographic distribution of plants and animals in the region and elucidate diversity patterns (e.g. Cody, 1986). The present study was commenced as part of a broader study to identify biogeographic patterns amongst a range of plant and animal groups in the south-western Australian wheatbelt, and to identify regions of high conservation value. Elsewhere (McKenzie et al., 2003) we investigated the effects of salinisation on small ground-dwelling animals in the Western Australian wheatbelt. In the present paper, we explore geographic patterns in the communities of small ground-dwelling vertebrates

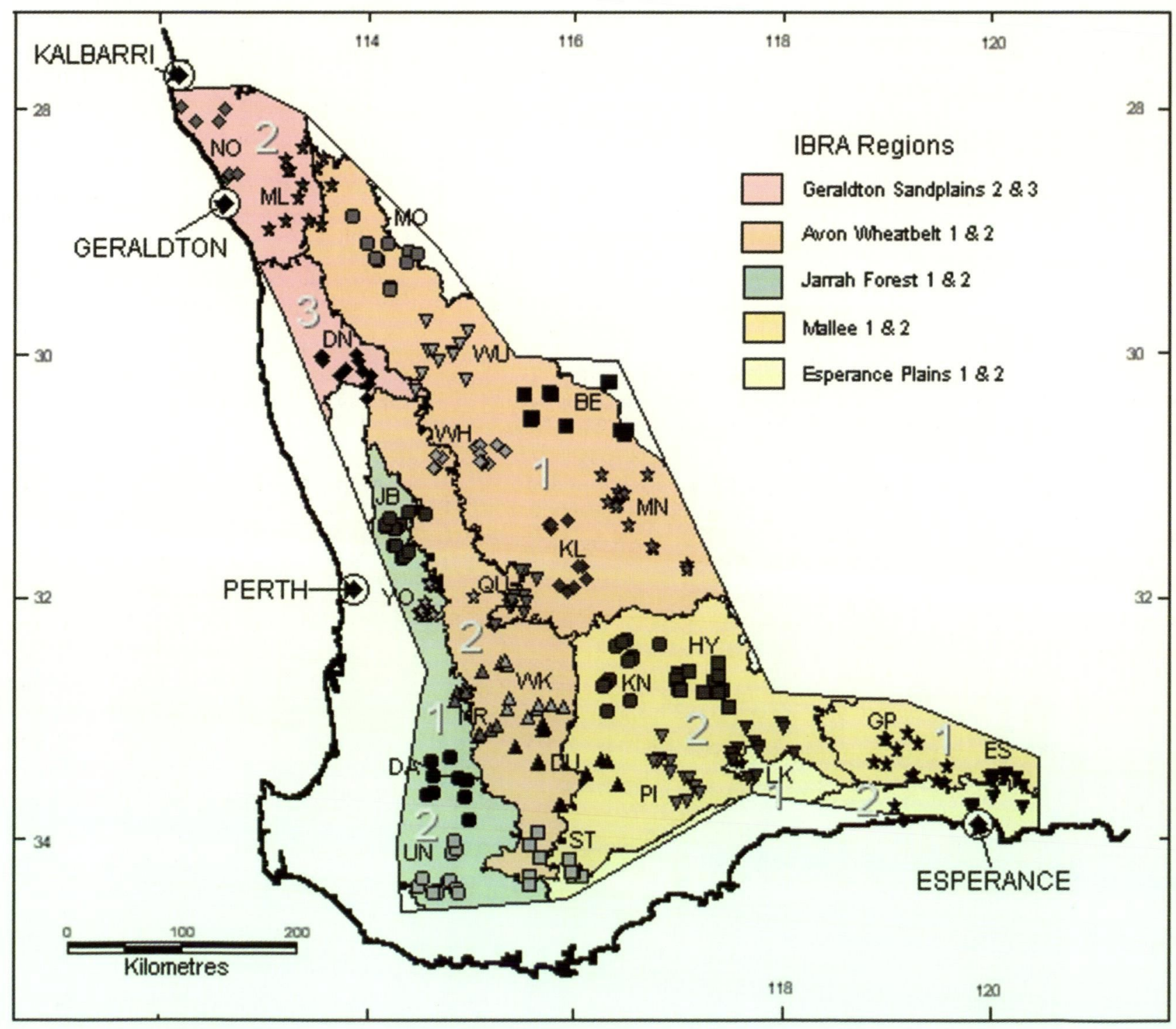

Figure 1 Wheatbelt study area, showing the 304 quadrats, and relevant biogeographical region boundaries (Thackway and Cresswell 1995). The different symbols indicate the 12 or 13 quadrats in each of the 24 survey areas. 
(frogs, reptiles and small mammals) at sites not overtly affected by secondary salinisation. Specifically, we examine patterns of species richness, explore compositional variation among sample sites (quadrats), provide an overview of the composition and distribution of species assemblages and document relationships between assemblage composition and characteristics of the physical environment.

\section{STUDY AREA AND METHODS}

The study area extended from near Northampton (latitude $28^{\circ} \mathrm{S}$ ) to near the south coast, and from near the west coast east to just beyond Esperance (longitude $123^{\circ} \mathrm{E}$ ) (Figure 1). The area is characterised by a Mediterranean climate with hot dry summers and most rainfall in winter. Annual rainfall ranges from $300 \mathrm{~mm}$ in the north-east to 800 $\mathrm{mm}$ in the south-west, annual average maximum temperature is between 24 and $37^{\circ} \mathrm{C}$ and annual average minimum temperature between 4 and $9^{\circ} \mathrm{C}$ (Bureau of Meteorology, 2001).

The landscape is an ancient one, dating from the Palaeozoic (McArthur, 1993). It is mantled with sand over lateritic gravel, with dissection and differential erosion of the old lateritic plateau surface resulting in a catenary of landforms and soils of colluvial, alluvial, lacustrine and aeolian origin and including sands, sandy loams and loams (sometimes over clay) low in the landscape. Soils in ancient drainage basins are saline, particularly in the north-eastern part of the study area (Mulcahy and Hingston, 1962; Bettenay and Hingston, 1964; Salama, 1994). Beard (1990 and references therein) described the sclerophyllous vegetation which is mainly woodlands low in the landscape and woodlands, shrublands and heathlands high in the landscape. An overview of the study area in relation to the component Interim Biogeographic Regionalisation of Australia (IBRA) bioregions (Thackway and Cresswell, 1995) is provided by McKenzie et al. (this volume).

As part of a wider survey carried out in the context of salinisation in the Western Australian wheatbelt (McKenzie et al., 2003, this volume), the $205000 \mathrm{~km}^{2}$ study area (Figure 1) was divided into 24 survey areas. These were positioned to allow sampling across the extent of the study area, and across all likely environmental gradients, in an efficient manner. Twelve or 13 quadrats, each of one hectare, were positioned to sample the geomorphic profile of each survey area. We positioned quadrats in the least-disturbed examples of each habitat type that we could find although we included pseudoreplicates in landform units that were affected by groundwater salinity. Sites affected by secondary salinisation are reported on in McKenzie et al. (2003, this volume); the current paper reports on those 252 sites not overtly affected by secondary salinisation. Landform units were numbered from 1 to 12 according to their position in the landscape profile (Figure 2). In cases where a unit was particularly extensive within a survey area, two quadrats were sampled. As well, most quadrats were pseudoreplicated in the other survey areas to allow for the internal heterogeneity of the stratification units (hypothesised scalars) and to minimise any analytical circularity introduced by stratification (Taylor and Friend, 1984; McKenzie et al., 1989). Further details concerning quadrat selection are provided in McKenzie et al. (2003). Locations of quadrats are given in Appendix 1.

Reptiles, frogs and mammals were pit-trapped at each quadrat for a minimum of seven nights in both spring and autumn. The minimum of seven nights was chosen to encompass a full weather cycle, with sampling in two seasons to optimise return for trapping effort (Moseby and Read, 2001; Read and Moseby, 2001). Quadrats in the first third of survey areas (central wheatbelt) were sampled from October 1997 to September 1998, while the northern quadrats were sampled from September 1998 to October 1999, and the southern ones, plus the Dandaragan Plateau, were sampled from October 1999 to October 2000.

For the first 101 quadrats surveyed, the minimum effort was 168 pit trap nights, using two lines of six pits, $10 \mathrm{~m}$ apart, at each quadrat. For the remaining quadrats, this was extended to 210 pit trap nights per quadrat, with three lines of five pits, $5 \mathrm{~m}$ apart. In addition to the extra pits, the extra line would have improved spatial coverage of the site. This would have increased the probability of encountering a given species at the site, thereby allowing us to have more confidence in our assumption of complete sampling. In all cases, a 25 $\mathrm{cm}$ high flywire drift-fence extended the length of the line. The pits were PVC pipe $125 \mathrm{~mm}$ diameter and $350 \mathrm{~mm}$ deep, had a plastic bottom (2 L jar) and included a cone-shaped baffle to hinder escapes. A variable amount of time was spent searching for reptiles by hand on each quadrat, depending on our assessment of how well the site had been sampled by the pit traps, based on our knowledge of the fauna of the region. The aim of sampling was to provide reliable presence/absence data for each quadrat, and any hand searching served to make this assumption more robust. Additional data came from accidental captures in invertebrate traps at the same quadrats (Harvey et al., this volume) and at a subset of quadrats from searching for frogs based on call recognition or sightings. Species were included in the analysis only if they were reliably captured by the sampling methods (see Rolfe and McKenzie, 2000). For example, the Quenda and a number of snake species are believed to be reasonably common in parts of the study area, but 
are known to be difficult to trap using our methods, and these were among the species excluded from the analyses. A full listing is provided in Table 2. This approach minimised the problems of unreliable 'absence' data in the presence-absence matrix. Voucher specimens have been lodged in the Western Australian Museum.

The analytical approach taken was an exploratory design based on the assumption that spatial distribution reflects an underlying correlation with environmental factors (Austin, 1991). A range of climatic, geomorphic, soil and vegetation attributes was derived for each quadrat (Table 1, Appendix 1). Eighteen climatic attributes were derived for each quadrat using ANUCLIM (McMahon et al., 1995). These comprised annual and seasonal average and range values for temperature and precipitation. There are varying degrees of correlation between these attributes, and these are reported in Appendix
2. Fifteen soil chemical and texture values for each quadrat were derived from sub-samples collected at a depth of $5-10 \mathrm{~cm}$ from 20 to 30 points, then bulked. These included nitrogen, phosphorus, potassium, $\mathrm{pH}$, electrical conductivity, organic carbon, clay-siltsand percentages and magnesium (c. f. McKenzie et al., 2000b). Correlations between attributes are shown in Appendix 2. Four landform and several vegetation attributes were also generated, including elevation, soil drainage category, slope, salinity risk, tree canopy, shrub cover, herb cover, litter/log cover and habitat complexity (modified from Newsome and Catling, 1979). Latitude and longitude were also obtained for each quadrat using a GPS unit, and included as physical variables in analysis procedures. Because landform had already been used to position the quadrats in each survey area, it was not used as an attribute in the compositional analyses.

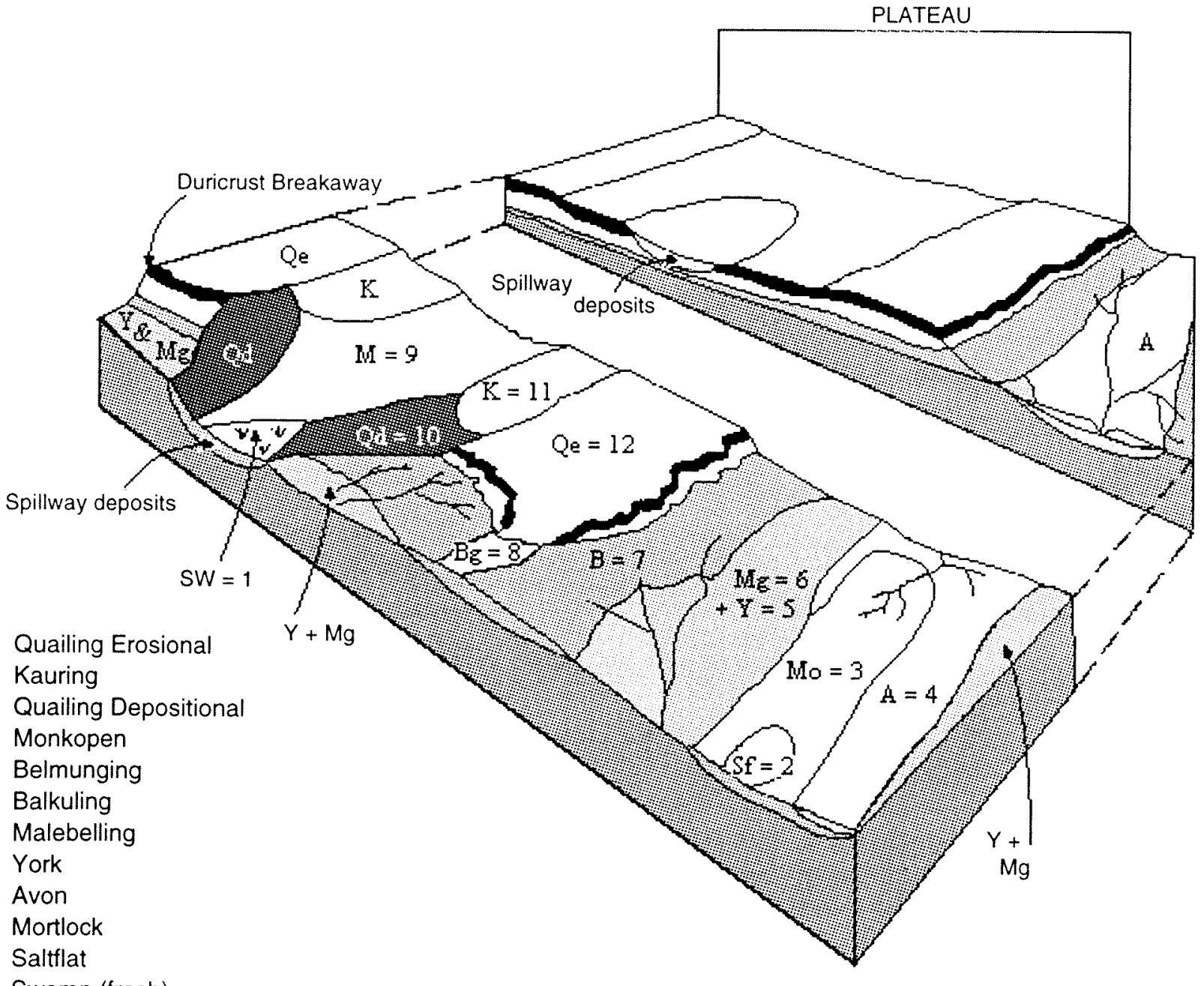

Sw Swamp (fresh)

Figure 2 Wheatbelt landforms, modified from Mulcahy and Hingston (1961). The landscape's plateau profile comprises the duricrusted Tertiary laterite plateau and its derived spillway sands, while the dissection profile comprises finer textured soils derived from bedrock and pallid-zone clays beneath the duricrust. The numbers against each landform are used in the text and elsewhere as labels for the landforms. 
Table 1 Environmental attribute codes. Climatic attributes were derived using ANUCLIM (McMahon et al., 1995).

\begin{tabular}{|c|c|c|c|}
\hline Code & Attribute & Code & Attribute \\
\hline PrecAnnu & Annual average precipitation ( $\mathrm{mm})$ & $\mathrm{Ex} \_\mathrm{Na}$ & Exchangeable sodium (me\%) \\
\hline PrecWetQ & Wettest quarter precipitation (mm) & Ex_a & Exchangeable calcium \\
\hline PrecWrmQ & Warmest quarter precipitation $(\mathrm{mm})$ & Ex_Mg & Exchangeable magnesium (me\%) \\
\hline Precseas & $\begin{array}{l}\text { Precipitation seasonality (see McMahon } \\
\text { et al., 1995) }\end{array}$ & Total N & Total nitrogen (ppm) \\
\hline MTAnnual & Annual average temperature (" $\mathrm{C})$ & $E x_{-\ldots} K$ & Exchangeable potassium (me\%) \\
\hline MTWetQtr & Wettest quarter mean temperature ("C) & $\mathrm{K}$ & Potassium (ppm) \\
\hline MTWrmQtr & Warmest quarter mean temperature $\left({ }^{\circ} \mathrm{C}\right)$ & $\mathrm{P}$ & Phosphorus (ppm) \\
\hline MnT_CP & Minimum temperature coldest period ("C) & OrgC & Organic carbon \\
\hline MTDryQtr & Mean temperature driest quarter (" $\mathrm{C})$ & $\mathrm{pH}$ & Soil pH \\
\hline MxT_WP & Maximum temperature warmest period $\left({ }^{\circ} \mathrm{C}\right)$ & EC & Electrical conductivity $\left(\mathrm{mS} \mathrm{m}^{-1}\right)$ \\
\hline MTDiuRng & Temperature diurnal range $\left({ }^{\circ} \mathrm{C}\right)$ & $\log E C$ & Log of electrical conductivity \\
\hline Temp_AR & Temperature annual range ("C) & Total_P & Total Phosphorus (ppm) \\
\hline \multirow[t]{3}{*}{ Isotherm } & Isothermality (see McMahon et al., 1995) & Impedence & Soil impedance \\
\hline & & A_horizon & Soil A horizon \\
\hline & & Sand & Per cent sand \\
\hline Dist_cst & Distance to coast $(\mathrm{km})$ & expSand & Exponent of sand \\
\hline Elev & Altitude $(\mathrm{m})$ & Clay & Per cent clay \\
\hline Lat & Latitude ("S) & Silt & Per cent silt \\
\hline Long & Longitude $\left({ }^{\circ} \mathrm{E}\right)$ & GrndStuf & $\begin{array}{l}\text { Logs, litter, etc on ground, 0-3 (modified } \\
\text { from Newsome and Catling, 1979) }\end{array}$ \\
\hline LF & Landform (see Figure 2) & GrndHerb & Ground herbs $(0-3)$ \\
\hline Drainage & Six categories, $1-6$ & ShrubCov & Shrub cover $(0-3)$ \\
\hline Slope & Five categories, $1-5$ & TreeCanp & Tree canopy $(0-3)$ \\
\hline $\operatorname{adjSAL}$ & $\begin{array}{l}\text { Adjusted salinity (modified from van Gool } \\
\text { and Moore, 1999; see Mckenzie et al, 2003) }\end{array}$ & $\mathrm{HCS}$ & $\begin{array}{l}\text { Habitat complexity score, 1-10 (modified } \\
\text { from Newsome and Catling, 1979) }\end{array}$ \\
\hline
\end{tabular}

Quadrats were assigned among four classes of salinity risk (SAL - modified from van Gool and Moore 1999; see Appendix 1. Classes 1 and 2 do not show any overt salinity; in classes 3 and 4 salinity is overt and variably widespread on quadrats. Class 4 includes 'natural' saltflats.

Mckenzie et al. (2003) showed that there is a negative relationship between the species richness and diversity of small ground-dwelling animals and increasing salinity in the Western Australian wheatbelt. In the present study, we investigated the relationship between vertebrate species richness and other physical attributes. In order to remove the known salinity effects, we confined our analyses to the 252 quadrats that had a low salinity risk score (1 or 2) or were naturally saline saltflats. The intention was to explore biogeographic patterns that may have existed in the study area before the advent of widespread salinisation that occurred over the last century. We used Kendall's Tau to determine the significance of the level of correlation between species richness and the values of each physical attribute.

Cluster analysis (from PATN; Belbin 1995) was used to expose patterns of quadrat similarity and species composition in the data matrix. Briefly, the Czekanowski association measure (Czekanowski, 1932) was used to compare the quadrats according to similarities in their species composition, and the association measure Twostep (Belbin, 1980) was used to determine the quantitative relationship between each pair of species as a basis for clustering species that normally co-occurred at the same quadrats. For both measures of association, a modified version of unweighted pair group arithmetic averaging hierarchical clustering strategy was used (UPGMA - Sneath and Sokal, 1973; Belbin, 1995), with the clustering parameter (Beta) set to -0.1. This procedure is appropriate for ecological presence-absence data and is robust to variations in species abundance patterns and hence sampling efficiencies (Faith et al., 1987; Belbin, 1991). The partition structure of the resulting quadrat-dendrogram was used as a summary of compositional patterns across the study area. Quadrat physical attributes that most closely conformed to the overall partition structure were assessed for statistical significance using KruskalWallis one-way analysis of variance by ranks (the GSTA module in PATN - Belbin, 1995).

However, while this approach is useful for examining the overall structure of the dendrogram, it obscures the relationships exhibited by most of the groups at the point where a group separated from the remainder of the dataset. We therefore used the simple stepwise approach of examining each fusion event separately. This provides a more detailed, and more realistic, interpretation of the relationships exhibited by the different components of the fauna. The level of significance between pairs of groups for individual physical attributes was 
Table 2 Vertebrate species recorded from the survey area in the Western Australian agricultural zone (from McKenzie et al., 2002; Storr et al., 1983, 1990, 1999, 2002; Tyler et al., 2000 and our field sampling program). Nomenclature is based on Aplin and Smith (2001) and How et al. (2001). For undescribed species a Western Australian Museum collection number is quoted. ${ }^{*}=$ introduced; $\mathrm{C}=$ contemporary occurrence in study area; $\mathrm{E}=\mathrm{Extinct}$; Es = extinct in study area; $\mathrm{T}=$ could be caught in our traps; $\mathrm{Q}=$ recorded on quadrats during our survey; $\mathrm{m}=$ occurs only on margin of our study area (compass direction in brackets)

\begin{tabular}{ll}
\hline AMPHIBIANS & \\
Hylidae & \\
Cyclorana platycephala & C T m(NE) \\
Litoria adelaidensis & C T Q \\
Litoria cyclorhyncha & C T Q \\
Litoria moorei & C T Q
\end{tabular}

\section{Myobatrachidae}

Heleioporus albopunctatus

Heleioporus barycragus

Heleioporus eyrei

Heleioporus inornatus

Heleioporus psammophilus

Limnodynastes dorsalis

Neobatrachus albipes

Neobatrachus centralis

Neobatrachus kunapalari

Neobatrachus pelobatoides

Neobatrachus sutor

Neobatrachus wilsmoret

Crinin georgiana

Crinia glauerti

Crinia pseudinsignifera

Crinia subinsignifera

Metacrinia nichollsi

Myobatrachus gouldii

Pseudophryne guentheri

Pseudophryne occidentalis

\section{REPTILES}

\section{Cheluidae}

Chelodina oblonga

\section{Agamidae}

Amphibolurus norris

Ctenophorus cristatus

Ctenophorus maculatus

Ctenophorus nuchalis

Ctenophorus ornatus

Ctenophorus reticulatus

Ctenophorus salinarum

Ctenophorus scutulatus

Ctenophorus sp A (R150282)

Ctenophorus sp B (R142275)

Lophognathus longirostris

Moloch horridus

Pogona minor

Rankinia adelaidensis

\section{Gekkonidae}

Crenadactylus ocellatus

Diplodactylus alboguttatus

Diplodactylus granariensis

Diplodactylus maini

Diplodactylus ornatus

Diplodactylus polyophthalmus

Diplodactylus pulcher

Diplodactylus squarrosus

Diplodactylus sp. (R136559)

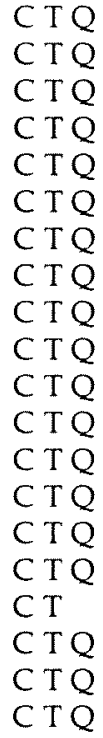

C T Q

$\mathrm{CQ}$

C T Q

CTQ

C T Q

C T Q

CTQ

C T

C T Q

CTQ

CTQ

CTQ

C T $\mathrm{m}(\mathrm{N})$

C T Q

CTQ

CTQ

C T Q

CTQ

CTQ

C T Q

C TQ

CTQ

C T Q

CTQ

CTQ
Nephrurus levis

Nephrums vertebralis

Oedura reticulata

C TQ

$\mathrm{CT}$

Strophurus michaelseni

C TQ

Strophurus spinigerus

Strophurus strophurus $\quad$ C T Q

Underwoodisaurus milii C TQ

Christinus marmoratus $\quad$ C TQ

Gehyra variegata C TQ

Heteronotia binoei $\quad \mathrm{CTQ}$

Pygopodidae

Aclys concinna C T

Aprasia pulchella $\quad$ C TQ

Aprasia repens $\quad \mathrm{CTQ}$

Aprasia smithi C T

Aprasia striolata $\quad \mathrm{CT}$

Delma australis $\quad$ C T Q

Delma butleri C T

Delma fraseri $\quad$ C T Q

Delmagrayii $\quad \mathrm{CT}$

Delma tincta C T

Delma sp ? nov (R130297) C T Q

Lialis burtonis $\quad \mathrm{CTQ}$

Pletholax gracilis $\quad \mathrm{CTQ}$

Pygopus lepidopodus $\quad$ C T Q

Pygopus nigriceps $\quad$ C TQ

Scincidae

Acritoscincus trilineatum

Cryptoblepharus carnabyi $\quad$ C T Q

Cryptoblepharus plagiocephalus $\quad$ C TQ

Cryptoblepharus virgatus $\mathrm{CT}$

Ctenotus alleni $\mathrm{CT}$

Ctenotus australis $\quad \mathrm{C} \mathrm{T} \mathrm{Q}$

Ctenotus catenifer $\quad \mathrm{CTQ}$

Ctenotus delli $\quad \mathrm{CTQ}$

Ctenotus fallens $\quad \mathrm{CTQ}$

Ctenotus gemmula C T Q

Ctenotus impar C T Q

Ctenotus labillardieri C T

Ctenotus leonhardii $\quad$ C T Q

Ctenotus mimetes $\quad \mathrm{CTQ}$

Ctenotus pantherinus CTQ

Ctenotus schomburgkii $\quad$ C T Q

Ctenotus uber CTQ

Ctenotus ?sp (R142614) C T Q

Cyclodomorphus branchialis $\quad$ C T Q

Cyclodomorphus celatus $\quad$ CT Q

Egernia depressa $\quad \mathrm{CT}$

Egernia inornata $\quad \mathrm{CTQ}$

Egernia kingii C

Egernia multiscutata $\quad$ C T Q

Egernia napoleonis $\quad$ C TQ

Egernia pulchra C T Q

Egernia richardi $\quad \mathrm{C} \mathrm{TQ}$

Egernia stokesii $\quad$ C T Q

Eremiascincus richardsonii $\quad \mathrm{CTQ}$

Hemiergis initialis $\quad$ C TQ

Hemiergis peronii $\quad \mathrm{CTQ}$ 
Table 2 (cont.)

\begin{tabular}{|c|c|}
\hline Lerista christinae & $\mathrm{CTQ}$ \\
\hline Lerista comizens & $\mathrm{CTQ}$ \\
\hline Lerista distinguenda & $\mathrm{CTQ}$ \\
\hline Lerista dorsalis & $\mathrm{CTQ}$ \\
\hline Lerista elegans & $\mathrm{CTQ}$ \\
\hline Lerista gerrardii & $\mathrm{CTQ}$ \\
\hline Lerista kendricki & $\mathrm{CTQ}$ \\
\hline Lerista lineopunctulata & $\mathrm{CTQ}$ \\
\hline Lerista macropisthopus & $\mathrm{CTQ}$ \\
\hline Leristn microtis & $\mathrm{CTQ}$ \\
\hline Lerista muelleri & $\mathrm{CTQ}$ \\
\hline Lerista planiventralis & $\mathrm{CTQ}$ \\
\hline Lerista praepedita & $\mathrm{CTQ}$ \\
\hline Lerista viduata & $\mathrm{CT}$ \\
\hline Lerista yuna & $\mathrm{CT}$ \\
\hline Menetia greyii & $\mathrm{CTQ}$ \\
\hline Menetia surda & $\mathrm{CTQ}$ \\
\hline Morethia adelaidensis & $\mathrm{CTQ}$ \\
\hline Morethia butleri & $\mathrm{CTQ}$ \\
\hline Morethia lineoocellata & $\mathrm{CTQ}$ \\
\hline Morethia obscura & $\mathrm{CTQ}$ \\
\hline Tiliqua occipitalis & $\mathrm{CQ}$ \\
\hline Tiliqua rugosa & $\mathrm{CQ}$ \\
\hline
\end{tabular}

\section{Varanidae}

Varanus brevicauda

Varanus caudolineatus

Varanus eremius

Varanus gouldii

Varanus rosenbergi

Varanus tristis

\section{Typhlopidae}

Ramphotyphlops australis

Ramphotyphlops hamatus

Ramphotyphlops leptosoma

Ramphotyphlops pinguis

Ramphotyphlops zuatii

\section{Boidae}

Antaresia perthensis

Antaresia stimsoni

Aspidites ramsayi

Morelia spilota

C

CTQ

CTQ

$\mathrm{CQ}$

$\mathrm{CQ}$

$\mathrm{CQ}$

$C Q$

$\mathrm{CQ}$

CT

CT

$\mathrm{CQ}$

C

c

C

$C Q$

\section{Elapidae}

Acanthophis antarcticus

Acanthophis pyrrhus

Brachyurophis fasciolata

Brachyurophis semifasciata

Demansin psammophis

Drysdalia mastersii

Echopsis curta

Elapognathus coronatus

Furina ornata

Neelaps bimaculatus

Neelaps calonotos

Notechis scutatus

Parasuta gouldii

Parasuta monachus

Parasuta nigriceps

Parasuta spectabilis

Pseudechis australis

Pseudonaja affinis
Psetidonaja modesta

Pseudonaja nuchalis

Rhinoplocephalus bicolor

Simoselaps bertholdi

Simoselaps littoralis

Suta fasciata

$\mathrm{C}$

$\mathrm{CQ}$

$\mathrm{C}$

$\mathrm{CQ}$

$\mathrm{C}$

C

\section{MAMMALS}

Tachyglossidae

Tachyglossus aculeatus

C

\section{Dasyuridae}

Antechinomys laniger $\quad$ C T Q

Antechinus flavipes C T Q

Dasycercus cristicauda Es

Dasyurus geoffroii $\quad$ C

Ningaui yoonneae $\quad \mathrm{CT}$ m(E)

Parantechinus apicalis $\quad \mathrm{CTm}(\mathrm{S})$

Phascogale calura

Phascogale sp. (south-west WA)

Sminthopsis crassicaudata

C

C

C TQ

CTQ

CTQ

CTQ

CTQ

CTQ

Sminthopsis sp. nov. (M53425)

C

Myrmecobius fascintus

\section{Peramelidae}

Chaeropus ecaudatus

Isoodon obesulus

Perameles bougainville

E

C

Es

\section{Thylacomyidae}

Macrotis lagotis

Es

\section{Potoroidae}

Bettongia lesueur

Bettongia penicillata

Potorous platyops

Es

C

Macropodidae

Lagorchestes hirsutus

Lagostrophus fasciatus

Macropus engenii

Macropus fuliginosus

Macropus irma

Macropus robustus

Macropus rufus

Onychogalea lunata

Petrogale lateralis

Setonix brachyurus

\section{Phalangeridae}

Trichosums vulpecula

Pseudocheirus occidentalis

\section{Burramyidae}

Cercartetus concinnus

Tarsipedidae

Tarsipes rostratus

C TQ 
Table 2 (cont.)

\section{Vespertilionidae}

Chalinolobus gouldii

Chalinolobus morio

Falsistrellus mackenziei

Nyctophilus geoffroyi

Nyctophilus gotildi

Nyctophilus timoriensis

Scotorepens balstoni

Vespadelus regulus

\section{Molossidae}

Mormopterus sp. 3

Mormopterus sp. 4 Pop O

Tadarida australis

\section{Muridae}

Hydromys chrysogaster

Leporillus apicalis

Leporillus conditor

Mus domesticus *

Notomys alexis

Notomys longicaudatus

Notomys macrotis

Notomys mitchellii

Pseudomys albocinereus

Pseudomys bolami

Pseudomys fieldi

Pseudomys hermannsburgensis

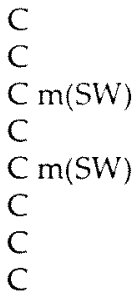

C

C

C

C

E

Es

C T Q

$\mathrm{CQ}$

E

E

$C Q$

CTQ

C T Q m(NE)

Es $T$

C TQm(N)
Psetidomys namus

Pseudomys occidentalis

Pseudomys shortridgei

Rattus fuscipes

Rattus rattus *

Rattus tunneyi

Leporidae

Oryctolagus cuniculus *

Canidae

Canis lupus dingo *

Vulpes vulpes *

Felidae

Felis catus *

Equidae

Equus caballus *

Suidae

Sus scrofo *

ET

CTQ

Es T

C T Q

C T

Es T

C

Es

C

C

C

C

Bovidae

Bos taurus *

Caprahircus *

Ovis aries *
C

C tested using Mann-Whitney $U$ tests. At each fusion point in the dendrogram's partition structure, starting from the top (two groups), we compared the two newly formed groups, provided each group had at least five members. For example, at the second fusion point there are three groups, but only one of the initial groups is divided so the resultant two 'new' groups were compared.

Species-groups identified from the species classification were interpreted in terms of the known habitat preferences of their component species throughout their ranges elsewhere in Australia (e.g. How et al., 1988; Storr et al., 1990; Ehmann, 1992; McKenzie et al., 1993; McKenzie et al., 2000a) and our previous field experience in other parts of Western Australia. The use of such extrinsic information on habitat preferences and distribution provides an indication of whether the classification is biologically meaningful. To aid interpretation of the species classification analyses we averaged the values of each physical parameter across all the quadrats where a given species was recorded, for each species.

Two frogs, Crinia pseudinsignifera and $C$. subinsignifera, could not be reliably differentiated morphologically. So, for the purposes of analysis, they were treated as one species and labelled $C$. pseudinsignifera.

\section{RESULTS}

\section{Intensity of sampling and comparison with the} historical record

During the survey we recorded a total of 144 vertebrate species belonging to 74 genera and 15 families and obtained a total of 9299 vertebrate animal by quadrat records (an average of 36.9 per quadrat) (Table 2). For the 252 quadrats sampled, anurans were recorded on 214 quadrats, mammals on 238 quadrats and reptiles on 250 quadrats. From 1 to 19 vertebrate species were recorded per quadrat, with an average of 10.4 (s.d. = 3.5). An additional two species (the skink Egernia stokesii at one quadrat and the snake Pseudonaja nuchalis at two quadrats) were caught at quadrats where secondary salinisation had commenced.

We recorded $22(92 \%)$ of the 24 anuran species known from the study area (Table 2). The exceptions were Metacrinia nichollsi and Cyclorana platycephala. From within the study area $M$. nichollsi is known only from a disjunct population in the Stirling Range. Cyclorana platycephala is an arid zone frog with a geographic range that extends only slightly into the north-east part of the study area; it is an explosive breeder requiring high rainfall events for activity that will generally occur over summer outside our sampling periods (Tyler, Smith and Johnstone, 2000). 
We recorded 106 (75\%) of the 142 reptile species known from the study area (Table 2). Some reptile species were not readily caught in our pit traps. They included the turtle Chelodina oblonga, the 33 snake species known from the area, the three largest skinks (Tiliqua rugosa, T. occipitalis, and Egernia kingii) and the four largest of the six Varanus species known from the area. Individuals of some of these species were occasionally recorded on our quadrats but were rarely, if ever, caught in the pit traps due to their size and/or ability to escape the pits. Similarly, Smith et al. (1997), working in the centre of our study area, found that legless lizards, monitors, blind snakes and snakes were rarely caught in pit traps. Species that were not readily caught were therefore under-sampled, occurred non-systematically in the data set and contributed little to estimation of similarity between sites or interpretation of pattern in the data, and so were excluded from further analyses. We judged that 101 reptile species were reliably 'pit trappable' and of these, we recorded $86(85 \%)$ and it is these that formed the basis of the following analyses.

There were 15 reptile species that we considered 'trappable', but which we did not catch. These included two dragons (Ctenophorus reticulatus and Lophognathus longirostris), one gecko (Nephrurus vertebralis), six pygopods and six skinks. These species were either very rare in the study area, confined to narrow environmental envelopes that we did not sample, present only at the margins of the study area (e.g. Lerista yuna), unlikely to be caught because they were only active under certain weather conditions, or perhaps capable of escaping from our traps.

We caught $15(88 \%)$ of the 17 'pit-trappable' native mammal species extant in the study area (McKenzie et al., 2002; Table 2), although capture of one of these species (Rattus fuscipes) was based on sub-adult individuals. One additional species, the introduced rodent $M u s$ domesticus, was also trapped. The original mammal fauna comprised 64 species, including 11 bats, and an additional 11 introduced species are known (Table 2). However, 17 native taxa (27\%) are now considered extinct in the study area and 41 species were too large to be trapped in our pits. Three of the species that are extinct in the study area (all rodents) would have been 'trappable' as adults using our techniques. Of these, Pseudomys nanus is extinct, while $P$. fieldi and Rattus tunneyi are regionally extinct but still occur outside our study area.

Of the four extant native species of appropriate size that we did not trap, Ningaui yoonneae barely penetrates the eastern margin of our study area and Parantechinus apicalis, while once more widespread, now occurs only near the southern margin of the survey area. Two of the hopping mice (Notomys alexis and $N$. mitchellii) are of a size that make them susceptible to being caught in our traps, but observations on captive individuals show that they easily escape. Furthermore, $N$. alexis only occurs on sandy substrates in the northern extremity of our study area.

Once the species that were ineffectively sampled by our trapping regime (see above) were removed from the data set, this left a total of 122 vertebrate species from the 252 quadrats: 21 anurans, 85 reptiles and 16 mammals (15 native and one introduced) (Table 2). The number of species per quadrat still ranged from 1 to 19 , but the average dropped slightly to $9.9($ s.d $=3.4)$.

\section{Patterns in vertebrate species richness}

The most widespread species, Mus domesticus, was found at $164(65 \%)$ of the 252 quadrats. Other frequently encountered species were the reptiles Lerista distinguenda (130), Menetia greyii (123), Morethia obscura (116) and Cryptoblepharus plagiocephalus (89) and the frog Pseudophryne guentheri (90). No native mammal occurred at more than 72 quadrats. Ten species, including four frogs, three reptiles and three mammals (including $\mathrm{Mus}$ ), were found on each of the 12 landforms we recognised.

Vertebrate species richness per quadrat varied significantly between landforms (Figures 2 and 3). 'Natural' saltflats (landform unit 2) showed significantly lower species richness than any other landform (4.4 vertebrate species per quadrat). Vertebrate species richness was highest on dissection valley floors (unit $3 ; 11.4$ species per quadrat) and sandy depositional surfaces on the old plateau (units 9-11; 11.3 - 11.5 species per quadrat).

Taken separately, overall patterns of species richness for frogs, reptiles and mammals across landforms were each generally similar to that for all vertebrates. To simplify this comparison, we combined the dissection valley quadrats (landforms $3-7$, excluding the swamps of landform 1 and saltflats of landform 2), and also combined the quadrats of the 'old plateau' (landform units 8-12) (Figure $3 \mathrm{~b}-\mathrm{h}$ ). Frog richness was significantly higher in freshwater swamps (Figure 3c), than in other landform types, and there was a higher species richness of frogs than reptiles or mammals at these sites (Figure $3 \mathrm{~d}-\mathrm{h}$ ). Within the frogs, the subfamily Myobatrachinae showed a similar pattern to the subfamily Limnodynastinae. Richness of reptiles and mammals was generally lower in swamps than in dissection valley quadrats or 'old plateau' quadrats (Figure $3 \mathrm{~d}-\mathrm{h}$ ).

Within the reptiles, patterns were similar for skinks, geckos and dragons except that, while for skinks species richness was similar across dissection valley and plateau sites, gecko richness was significantly higher, and dragon richness significantly lower, on dissection valley quadrats, 


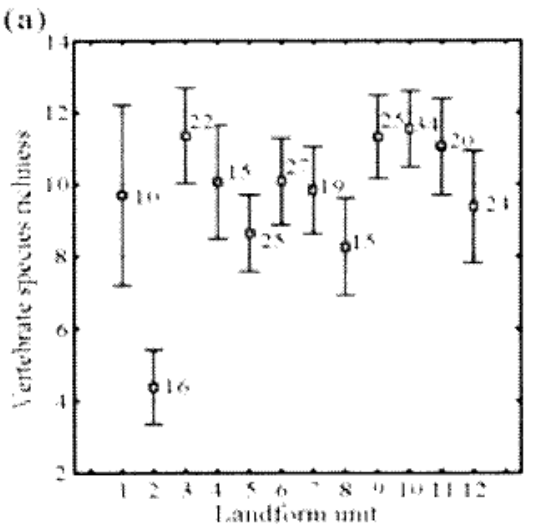

(c)
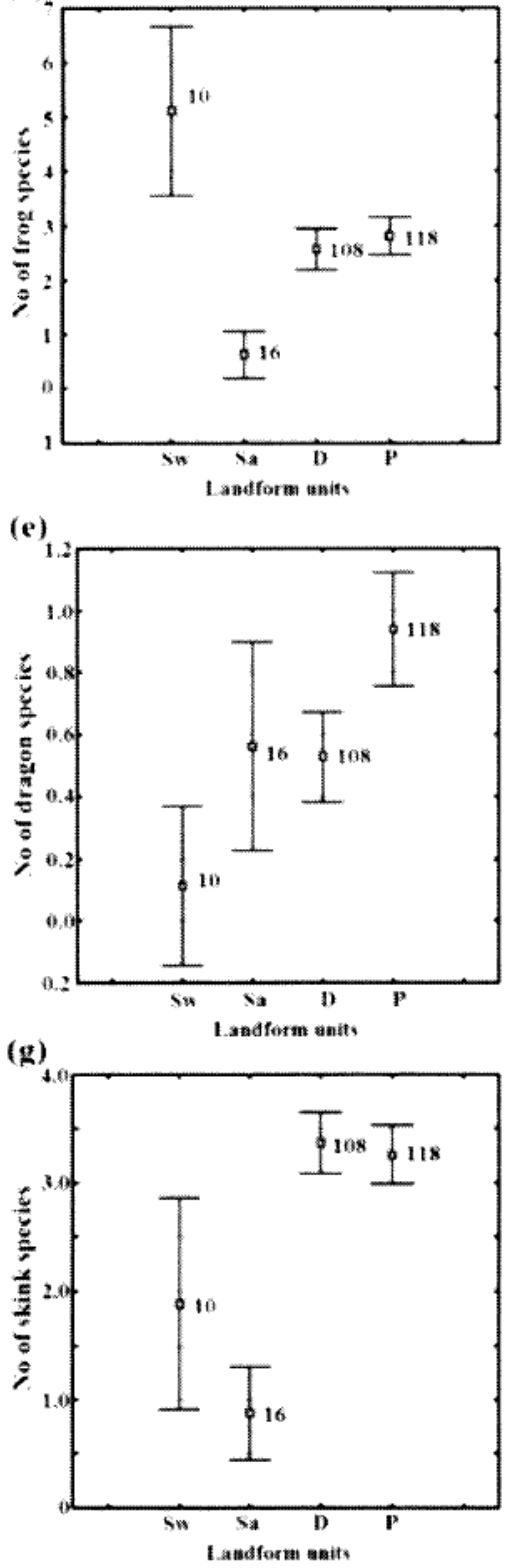

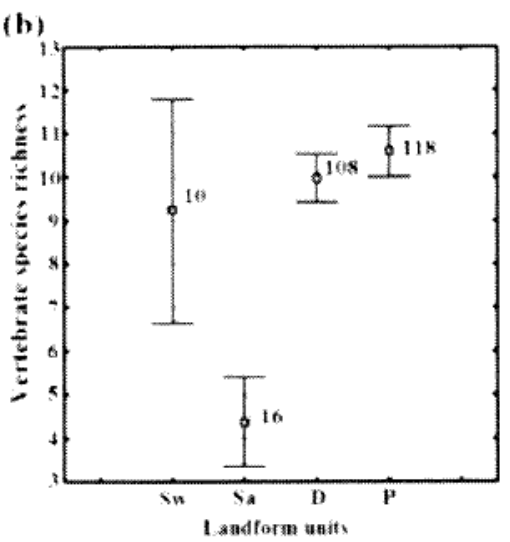

(d)
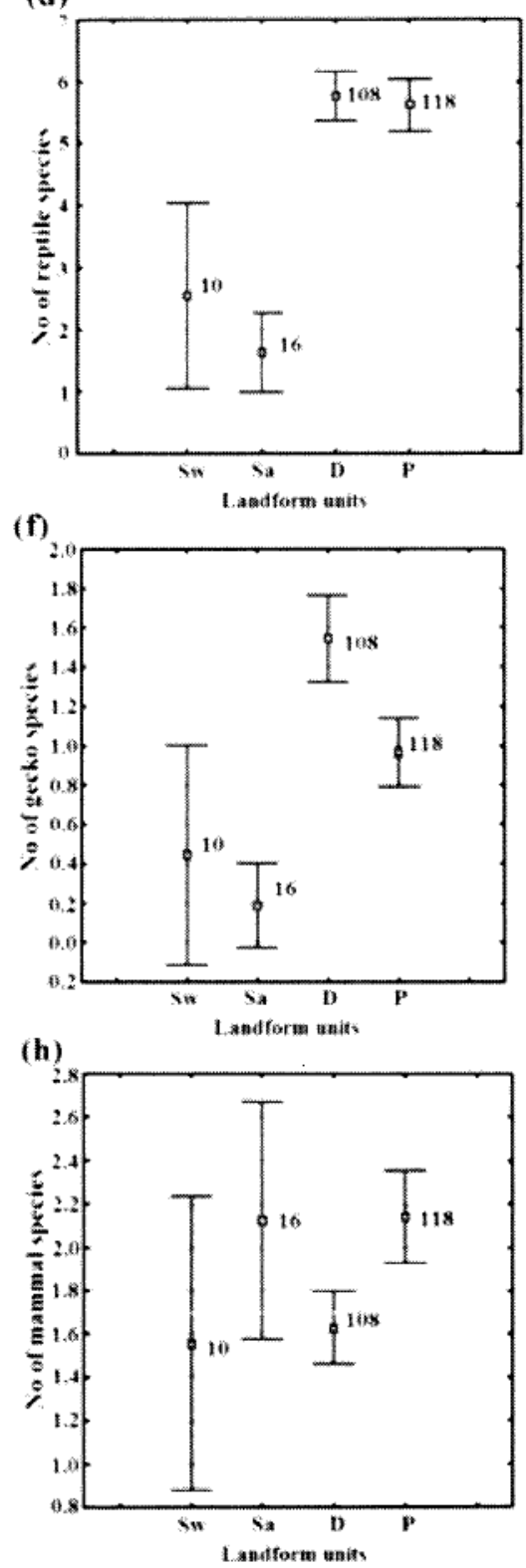

Figure 3 Relationship between quadrat species richness and landform unit, for the 252 quadrats not overtly affected by secondary salinisation, including those 'naturally' saline. Mean and $95 \%$ confidence limits are displayed. The number of quadrats sampled in each landform is given next to the mean. (a) Mean species richness for all vertebrates for each of the 12 landforms recognised; (b-h) mean species richness for various groups for swamps $\left(\mathrm{Sw}_{\mathrm{w}}=\right.$ swamps - landform unit 1$)$, 'natural' saltflats $(\mathrm{Sa}=$ saltflats - unit 2$)$, dissection profile quadrats (D - units 3-7) and 'old plateau' quadrats ( $\mathrm{P}$ - units 8-12): (b) all vertebrates, (c) frogs, (d) reptiles, (e) dragons, (f) geckos, (g) skinks, (h) mammals. 
where the best developed woodlands occur (Figure $3 e-g)$.

Mammals were different in that natural saltflats (unit 2) were as rich in species as most other units.

An analysis of the level of correlation between species richness and the values of each physical attribute showed that total vertebrate species richness was negatively correlated with salt and soil nutrients, and positively correlated with sand and soil drainage (Table 3). Taken separately, there were some differences between anurans, reptiles and mammals. Anuran species richness was significantly, positively correlated with deep sands and negatively correlated with soil nutrients and salinity. Rainfall was also significant, but with lower (positive) correlation coefficients. Rainfall attributes showed the highest positive correlation values in relation to species richness of frogs in the subfamily Myobatrachinae, but not for the Limnodynastinae, for which no climatic attributes were significant. Total reptile species richness was positively correlated with drainage, and negatively with salinity and soil nutrients. There were some differences between skinks, geckos and dragons.

Table 3 significant correlations between species richness and physical attributes, based on 252 quadrats with no salinity risk or low probability of risk/only partially affected or 'natural' saltflats. Attribute codes are explained in Table 1. Values given are Kendall Tau. Blank cells indicate that correlation was not significant; only correlations with $P<0.001$ are included. Values in bold indicate probability values of 0.000001 or less. The strength of correlations between variables is shown in Appendix 2.

\begin{tabular}{|c|c|c|c|c|c|c|c|c|c|c|}
\hline Attribute & $\mathrm{n}$ & $\begin{array}{c}\text { All } \\
\text { vertebrates }\end{array}$ & Anurans & $\begin{array}{l}\text { Myob } \\
\text { frogs }\end{array}$ & $\begin{array}{l}\text { Limno } \\
\text { frogs }\end{array}$ & Reptiles & Dragons & Geckos & Skinks & Mammals \\
\hline A_horizon & 242 & 0.14 & 0.20 & 0.21 & 0.16 & & & & & \\
\hline adjSAL & 252 & -0.18 & -0.17 & & -0.17 & -0.15 & & & -0.15 & \\
\hline Clay & 246 & & -0.20 & -0.17 & -0.19 & & & & & \\
\hline Dist_cst & 252 & & -0.16 & -0.18 & & & & & & \\
\hline Drainage & 252 & 0.26 & 0.16 & 0.10 & 0.17 & 0.21 & & & 0.22 & \\
\hline $\mathrm{EC}$ & 252 & -0.27 & -0.22 & -0.14 & -0.23 & -0.19 & -0.22 & & & \\
\hline Elev & 252 & & -0.16 & -0.14 & & 0.17 & 0.14 & 0.13 & & \\
\hline $\mathrm{Ex} \_\mathrm{Ca}$ & 252 & -0.14 & -0.16 & & -0.20 & & -0.25 & & & \\
\hline Ex_K & 252 & -0.25 & -0.22 & -0.17 & -0.24 & & -0.20 & & & \\
\hline Ex_Mg & 252 & -0.20 & -0.18 & & -0.22 & & -0.26 & & & \\
\hline $\mathrm{Ex} \_\mathrm{Na}$ & 252 & -0.26 & -0.19 & & -0.23 & -0.19 & -0.22 & & -0.15 & \\
\hline expsand & 246 & 0.21 & 0.24 & 0.17 & 0.24 & & 0.16 & & & \\
\hline GrndHerb & 252 & & 0.15 & 0.27 & & & -0.17 & & & -0.30 \\
\hline GrndStuf & 252 & & & & & & -0.14 & 0.10 & 0.16 & \\
\hline $\mathrm{HCS}$ & 252 & & & 0.19 & & & -0.21 & & & -0.24 \\
\hline Impedenc & 251 & & & & & & -0.14 & & & \\
\hline Isotherm & 252 & & & & & & -0.16 & -0.22 & & \\
\hline K & 252 & -0.23 & -0.23 & -0.19 & -0.23 & & -0.18 & & & \\
\hline Lat & 252 & & & & & & -0.26 & -0.17 & & \\
\hline $\log E C$ & 252 & -0.27 & -0.22 & -0.14 & -0.23 & -0.19 & -0.22 & & & \\
\hline Long & 252 & & & -0.16 & & & & & & 0.17 \\
\hline MnT_CP & 252 & & 0.14 & 0.17 & & & & & -0.14 & \\
\hline MTAnnnual & 252 & & & & & & 0.24 & 0.14 & -0.16 & \\
\hline MTDiuRng & 252 & & -0.16 & & & & 0.26 & 0.21 & & \\
\hline MTDryQtr & 252 & & & & & & 0.19 & 0.18 & -0.14 & \\
\hline MTWetQtr & 252 & & & & & & 0.16 & & -0.22 & \\
\hline MTWrmQtr & 252 & & & & & & 0.24 & 0.18 & -0.14 & \\
\hline MxT_WP & 252 & & & & & & 0.25 & 0.20 & & \\
\hline OrgC & 252 & & & & & & -0.29 & & & \\
\hline $\mathrm{P}$ & 252 & -0.25 & & & -0.14 & -0.20 & -0.30 & & & -0.19 \\
\hline $\mathrm{pH}$ & 252 & & -0.13 & -0.22 & & & & & & \\
\hline PrecAnnu & 252 & & 0.18 & 0.26 & & & -0.22 & & 0.15 & \\
\hline PrecSeas & 252 & & & 0.17 & & & & & & \\
\hline PrecWetQ & 252 & & 0.15 & 0.28 & & & -0.17 & & & -0.16 \\
\hline PrecWrmQ & 252 & & & & & & & -0.17 & & \\
\hline Sand & 246 & 0.21 & 0.24 & 0.17 & 0.23 & & 0.16 & & & \\
\hline ShrubCov & 252 & & & & & & 0.17 & & & \\
\hline Silt & 246 & -0.21 & -0.18 & & -0.18 & & -0.12 & & & -0.14 \\
\hline Slope & 252 & & & & & & 024 & 023 & & \\
\hline Temp_AR & 252 & & -0.14 & & -0.16 & & $\begin{array}{r}0.24 \\
-0.32\end{array}$ & & & -0.15 \\
\hline $\begin{array}{l}\text { Total_N } \\
\text { Total_P }\end{array}$ & $\begin{array}{l}252 \\
252\end{array}$ & $\begin{array}{l}-0.15 \\
-0.26\end{array}$ & -0.24 & & -0.26 & & -0.20 & & & -0.17 \\
\hline $\begin{array}{l}\text { Total P } \\
\text { TreeCanp }\end{array}$ & $\begin{array}{l}252 \\
252\end{array}$ & -0.26 & & & & & -0.31 & 0.17 & 0.21 & \\
\hline
\end{tabular}




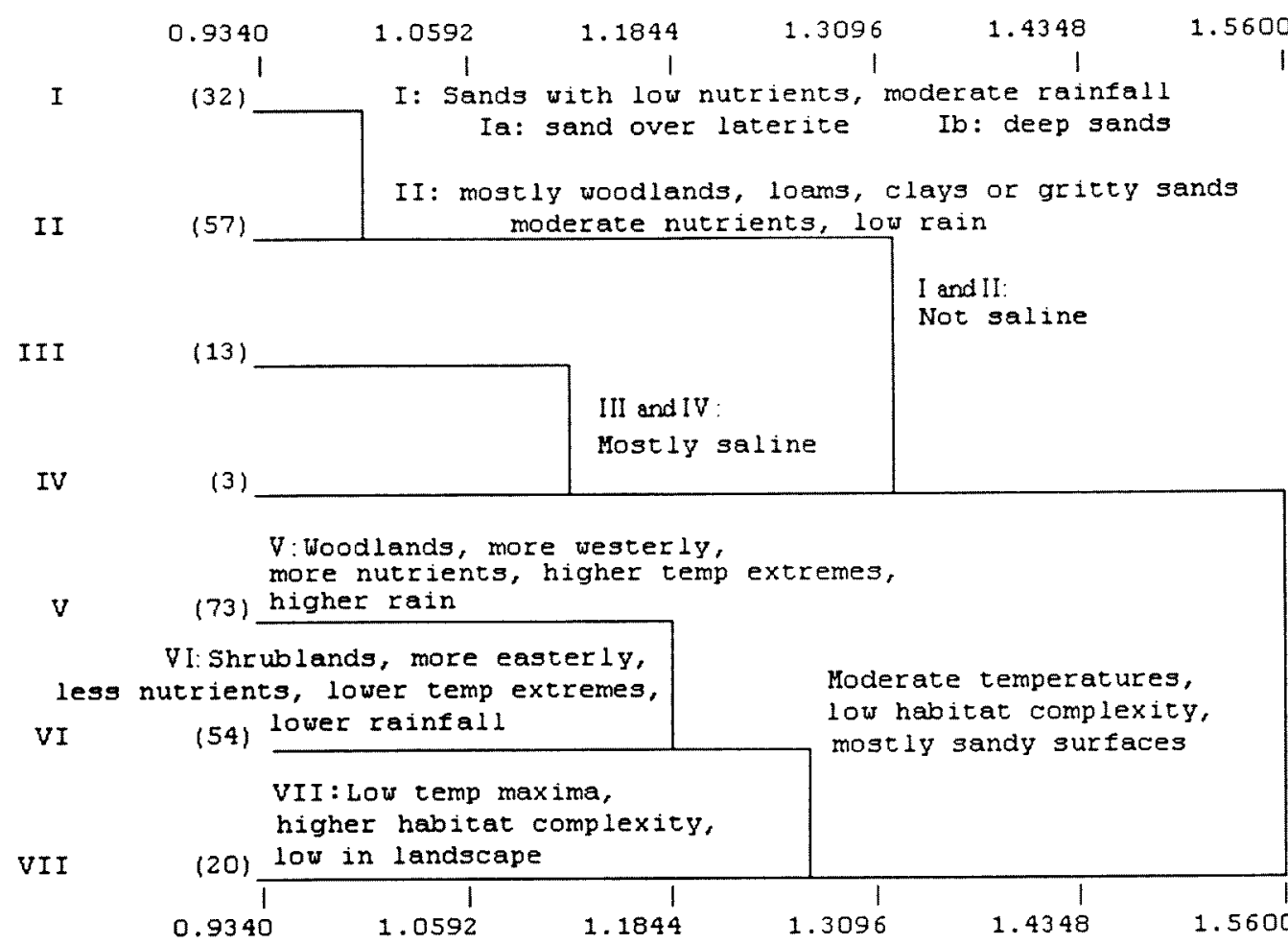

Northern and north-eastern

South-eastern and south-western

Figure 4 Dendrogram resulting from the classification of the 252 sample quadrats that were unaffected by secondary salinisation (see text for details), classified on the basis of vertebrate species composition.

Skinks and geckos both showed significant positive correlations with the presence of a tree canopy, whereas dragons showed a negative correlation. Skinks showed negative correlations with temperature attributes and positive correlations with rainfall attributes, whereas geckos and dragons showed positive correlations with temperature attributes and negative correlations with rainfall attributes. Mammal species richness was negatively correlated with habitat complexity scores and soil nutrient levels, and positively correlated with sand.

\section{Compositional variation among sample sites}

In this analysis, the 252 quadrats that had no overt signs of secondary salinity were classified on the basis of vertebrate species presence/absence, i.e. classified in terms of their species composition. Seven major quadrat groups (I-VII; Figure 4) could be recognised, and further structuring in the dendrogram was evident below this point. At the seven group level, the quadrat groups could be distinguished on the basis of maximum temperature of the warmest period, and salinity (Figure 5).

The final fusion in the dendrogram (point 2 in Figure 4) was between Groups I to IV (105 quadrats primarily from the semi-arid inland northern and north-eastern parts of the study area) and Groups V to VII (147 quadrats from the mesic southern and south-western parts of the study area) (Figure 6), associated with a northern and southern fauna respectively. Species with high levels of fidelity with the northern group included Lerista muelleri, Ctenotus mimetes, Gehyra variegata and Sminthopsis dolichura, and with the southern group, $L$. distinguenda, Morethia obscura and Cercartetus concinnus (Figure 10). Physical attributes that showed significant differences between these two groups were primarily climatic (Table 4), with maximum temperature of the warmest period (Figure 7) having the highest significance.

The last fusion within the northern group (point 3 in Figure 4) was between 16 quadrats with comparatively high salt levels (Groups III and IV) and 89 quadrats with lower salt levels (Groups I and II) (Table 4). Most of the 16 quadrats with high salt levels were in the inland parts of the study area, and 13 of them were on 'natural' saltflats. Ctenophorus salinarum and Sminthopsis crassicaudata were encountered at most of these saline quadrats, but many species, e.g. Gehyra variegata and Sminthopsis dolichura, were absent (Figure 10). Two of the quadrats in this set (ML11 and WH10) were not saline, but were very hard surfaces, and speciespoor. Within the set of quadrats with lower salt levels, the last fusion was between 32 quadrats (Group I) having relatively high rainfall and low nutrient levels, with 57 quadrats (Group II) having low rainfall and higher nutrient levels. Group I quadrats were predominantly on sands, with or without laterite present in the soil profile, with 
(a)

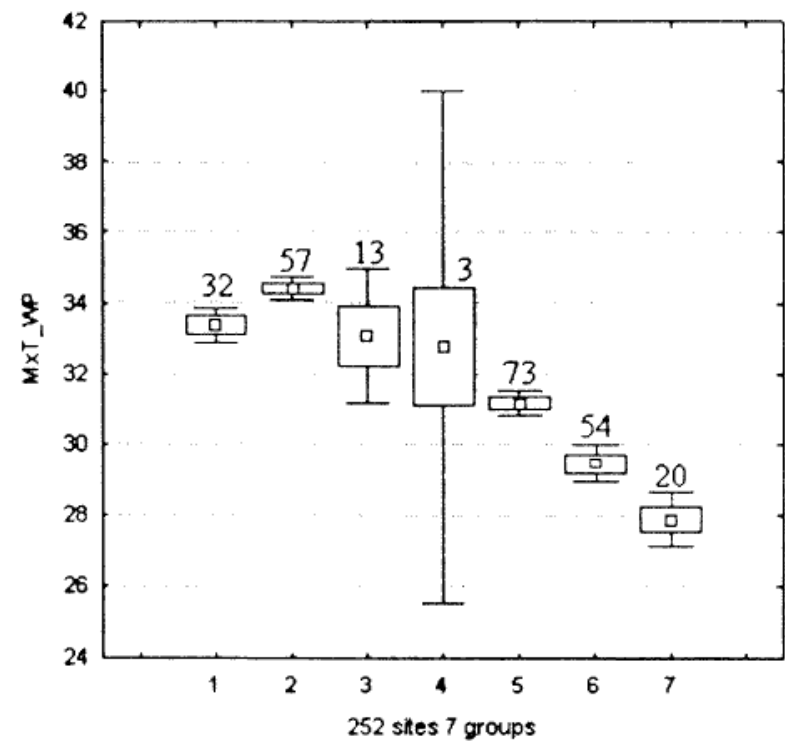

(b)

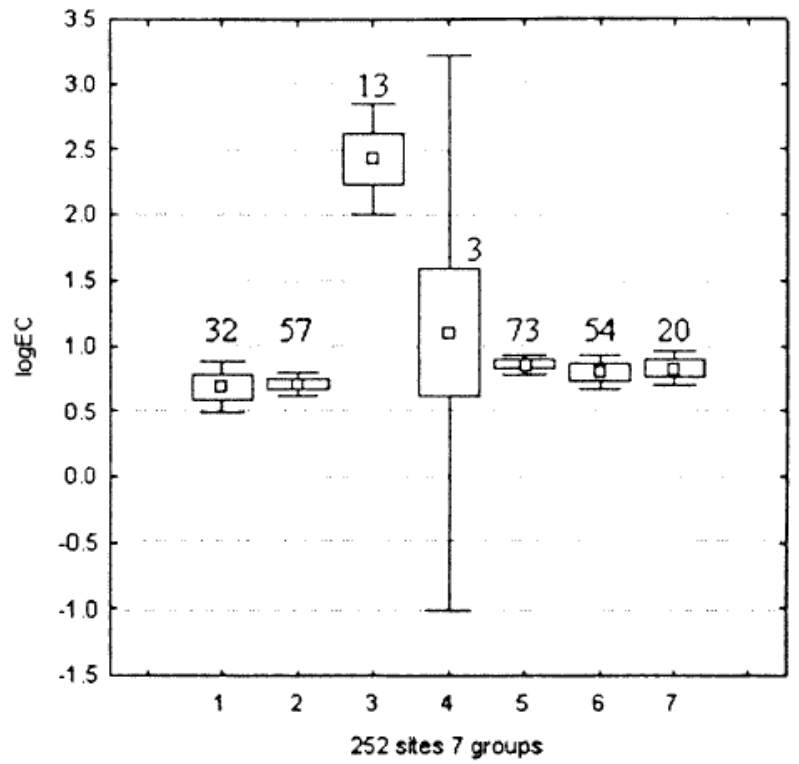

Figure 5 Comparison of (a) the maximum temperature of the warmest period $\left(\mathrm{MxT}\right.$ _WP; ${ }^{\circ} \mathrm{C}$ ) and (b) $\log \mathrm{EC}$ for the seven major groups in the dendrogram from the classification of 252 sites not overtly affected by secondary salinisation, including those naturally saline.. Mean and $95 \%$ confidence limits are shown; means are labelled with the number of quadrats in that partition. Results of Kruskall-Wallis tests are as follows: MxT_WP H = 158.6, $P<0.00001 ; \log E \mathrm{CH}=49.3, P<0.00001$. Other significant variables are also listed in Table 4.

shrublands or low woodlands, while Group II quadrats were predominantly on loams and clays, or gritty sands associated with granites, often supporting woodlands. The higher rainfall group comprised two subgroups: an inland subgroup (Ia, 16 quadrats), where quadrats occurred mostly on sands over laterite and had significantly lower rainfall than the coastal subgroup (Ib, 16 quadrats) of sites that were mostly deep sands, with some clays or loams (Figure 4, Table 4).

The last fusion within the southern set of 147 quadrats (point 4 in Figure 4) was between 20

Table 4 Differences in physical attributes between the two groups at each higher order fusion point in the dendrogram resulting from the classification of 252 quadrats that had no overt signs of secondary salinisation, or were naturally saline, on the basis of vertebrate species composition, using Mann-Whitney $U$ tests. Other significant attributes are listed in order of decreasing significance. Fusions involving a group with five or less quadrats are omitted from the table.

\begin{tabular}{|c|c|c|c|c|}
\hline $\begin{array}{l}\text { Total } \\
\text { number of } \\
\text { groups at } \\
\text { this point }\end{array}$ & $\begin{array}{l}\text { Physical } \\
\text { attribute with } \\
\text { highest } \\
\text { significance }\end{array}$ & $\mathrm{z}$ value & $p$ & $\begin{array}{l}\text { Other significant attributes, in decreasing order } \\
\text { (only attributes with significance }<0.0001 \text { are listed) }\end{array}$ \\
\hline 2 & MxT_WP & 11.52 & $<0.0001$ & $\begin{array}{l}\text { MTWrmQtr, MTAnnual, Temp_AR, MTWetQtr, Lat, PrecAnnu, } \\
\text { MTDiuRng, Isotherm, MTDryQtr, OrgC, Dist_cst, PrecWrmQ } \\
\text { PrecWetQ, TreeCanp, GrndStuf, Long }\end{array}$ \\
\hline 3 & $\log E C$ & -5.29 & $<0.0001$ & $\mathrm{EC}, \mathrm{Ex} \_\mathrm{Na}$, adjSAL, Drainage, $\mathrm{pH}, \mathrm{Ex} \_\mathrm{Mg}$ \\
\hline 4 & MTWrmQtr & 5.43 & $<0.0001$ & $\begin{array}{l}\text { Lat, PrecAnnu, MTDiuRng, Temp_AR, MTDryQtr, MxT_WP, } \\
\text { MTAnnual, HCS, PrecWrmQ GrndHerb }\end{array}$ \\
\hline 5 & Long & -7.56 & $<0.0001$ & $\begin{array}{l}\text { PrecWrmQ, PrecSeas, PrecWetQ Isotherm, Total_P, MxT_WP, } \\
\text { OrgC, Total_N, Temp_AR, PrecAnnu, MTDryQtr, MTWrmQtr, } \\
\text { MTDiuRng, Lat, Slope }\end{array}$ \\
\hline 7 & PrecAnnu & 5.05 & $<0.0001$ & Total_P, K, PrecWetQ, Temp_AR \\
\hline 8 & Ex_Mg & -4.4 & $<0.0001$ & Total_N, Ex_Ca, EC, logEC, Ex_Na \\
\hline 10 & PrecWetQ & -4.75 & $<0.0001$ & PrecAnnu, Dist_cst, Long, PrecSeas, MnT_CP, Isotherm, Elev \\
\hline 12 & PrecWrmQ & -3.94 & $<0.0001$ & \\
\hline 16 & Ex_Ca & 4.5 & $<0.0001$ & Ex_Mg \\
\hline 20 & MTWrmQtr & -4.26 & $<0.0001$ & MTAnnual, MxT_WP, Lat \\
\hline 24 & MnT_CP & -3.95 & $<0.0001$ & \\
\hline
\end{tabular}




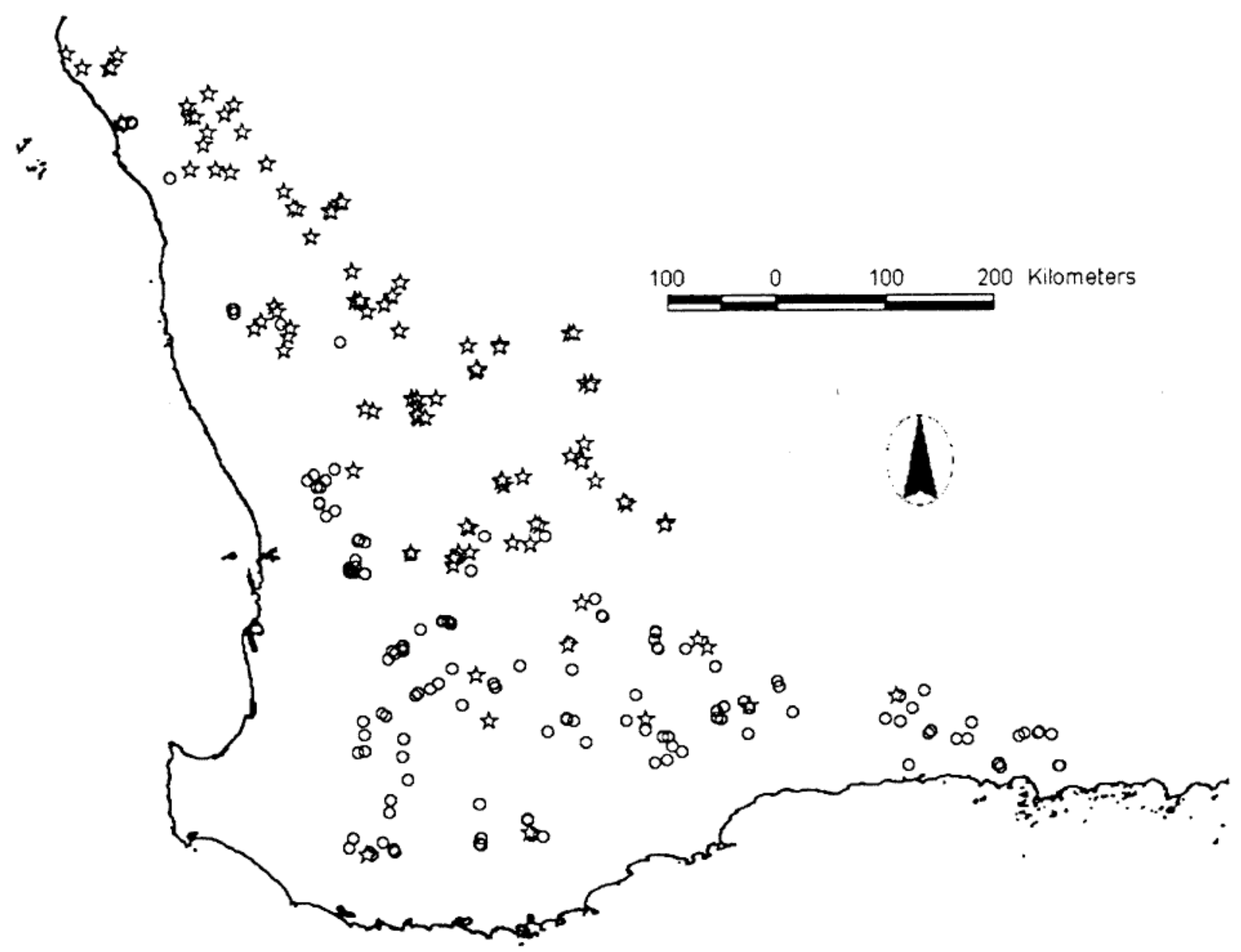

Figure 6 Geographic distribution of quadrats in the first two partitions of the quadrat classification.. Stars are quadrats in groups I to IV, circles are quadrats in groups V to VII.

quadrats located near lakes or gullies, or otherwise low in the landscape and relatively close to the coast (Group VII), and 127 quadrats (Groups V and VI) generally on sandy surfaces higher in the landscape and generally further inland. The physical attributes with highest significance were primarily climatic (Table 4), with maximum temperature of the warmest quarter having the highest significance (Figure 7). Habitat complexity was also higher in Group VII.

The 128 quadrats comprised a south-western set, mostly supporting woodlands, (Group V, 73 quadrats) and a southern set, mostly supporting shrublands (Group VI, 54 quadrats). Again, the physical attributes with highest significance were primarily climatic, or were correlated with rainfall (organic carbon). Within Group V, the 57 quadrats in sub-group Va often supported eucalypt woodlands, sometimes near granites, and had significantly higher values of exchangeable calcium than the 16 quadrats of sub-group $\mathrm{Vb}$, which were primarily shrublands or Banksia woodlands. Group VI, which was distributed throughout the landscape, could also be divided into sub-groups, with the 20 quadrats of VIa mostly being on creamy, yellow or grey sands having significantly higher values of exchangeable magnesium than the 34 quadrats of $\mathrm{VIb}$, which were mostly brown or grey loams and clays.

\section{Species assemblages}

The classification of the 122 species, according to their co-occurrence at the same quadrats, resulted in a dendrogram in which 12 groups could be recognised (Figure 8). The final fusion in this dendrogram was between a set (Groups 1 to 5) with predominantly south-western (mesic or semi-arid) distributions (67 species) and another (Groups 6 to 12) with predominantly arid or northern distributions (55 species) (Figure 8 ). Species that commonly occurred in the first set (Figure 10) included Morethia obscura and Lerista distinguenda, both of which have southern distributions on generally sandy or loamy soils in shrublands and woodlands. Some species in the first set (e.g. Menetia greyii), were very widespread within and beyond the study area. Species that were widespread in the second group included Gehyra variegata and Sminthopsis dolichura, both inhabitants of semi-arid woodlands. When physical attributes were compared between these two groups, the attribute with the highest level of significance was 


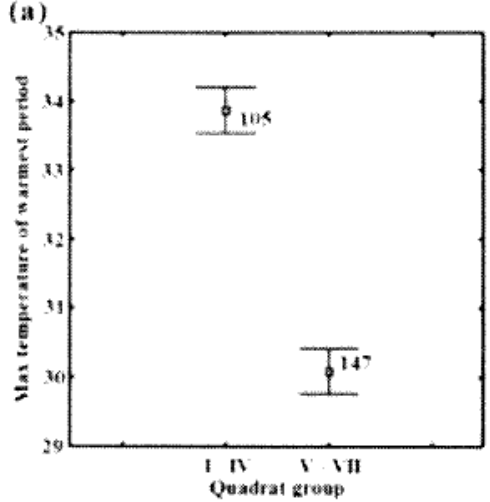

(c)

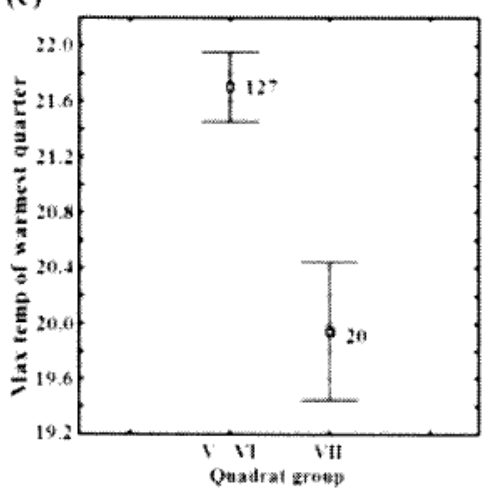

(e)

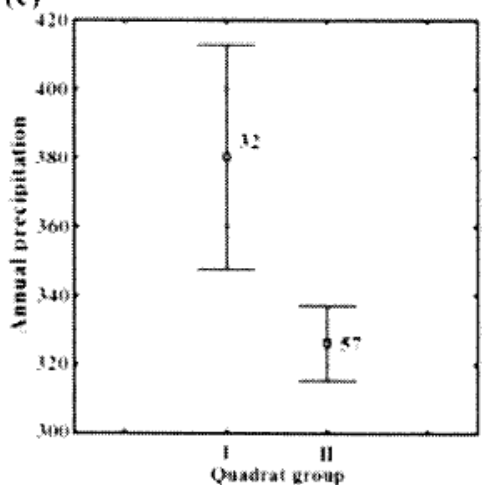

(g)

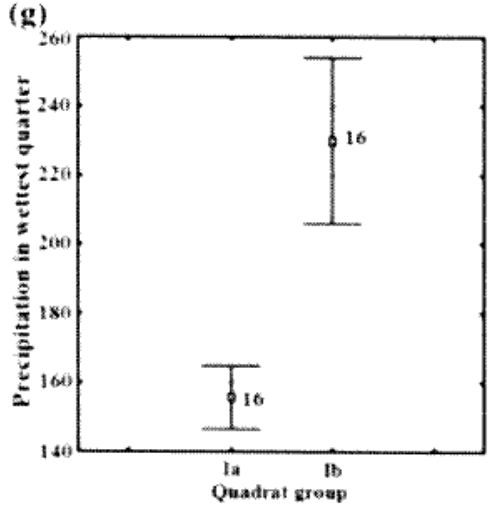

(b)

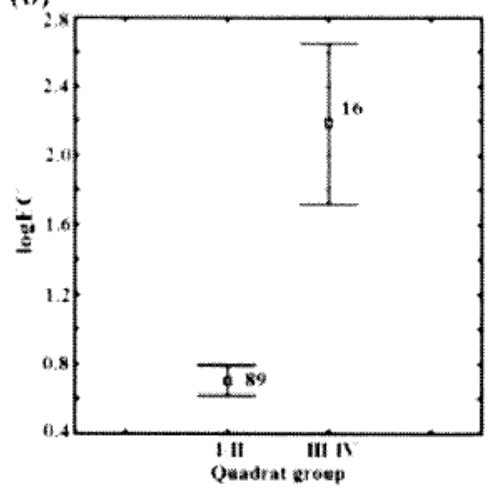

(d)

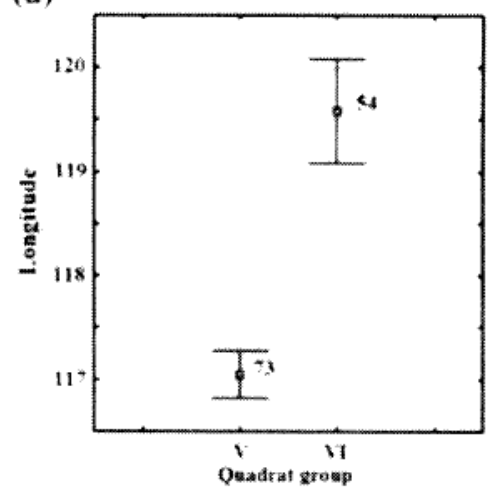

(f)

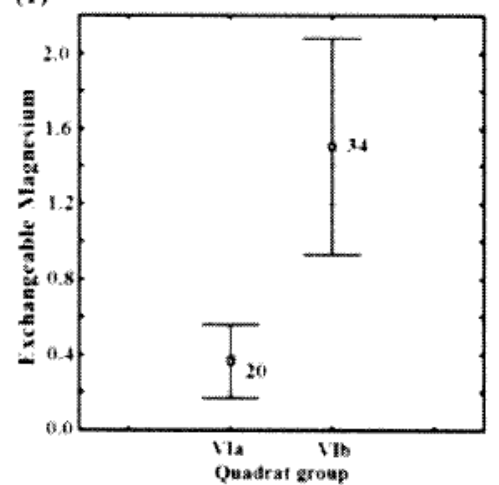

(h)

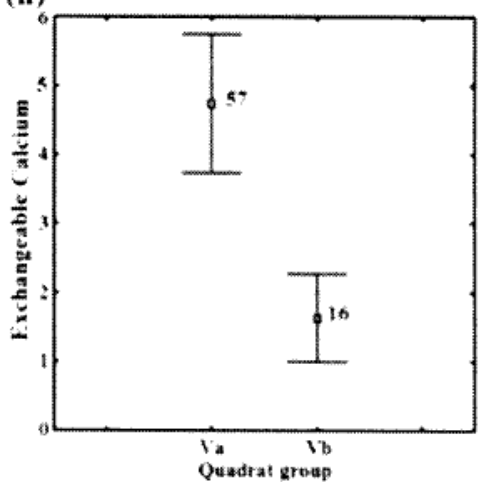

Figure 7 Comparison of attributes with the highest significance for the major fusion points in the dendrogram from the classification of 252 sites not overtly affected by secondary salinisation, including those naturally saline (see Figure 4). (a) Maximum temperature of the warmest quarter for the two final partitions (joining Groups I-IV with V-VII; point 2 in Figure 4), (b) $\log$ EC at the next fusion point (joining Groups I-II with III-IV), (c) maximum temperature of the warmest quarter (Groups V-VI with VII), (d) longitude for Groups V with VI, (e) annual precipitation for Groups I with II, (f) exchangeable Magnesium for Groups VIa and VIb, (g) precipitation in the wettest quarter for Groups $\mathrm{Ia}$ and $\mathrm{Ib}$, and (h) exchangeable Calcium for Groups Va and $\mathrm{Vb}$. Mean and $95 \%$ confidence limits are shown; means are labelled with the number of quadrats in that partition. Results of Mann-Whitney tests on these comparisons are given in Table 4. Other significant variables are also listed in Table 4 . 
1 (14) Mesic distributions, inhabiting mist, usually sandy sites

2 (B) Megic or seroi-arid digtributiong

3 (33) Widespread spg,

mogtly on sandy sites

4 (5) Spp preferring gandy siteg

5 (7) Spp inhabiting gandy gemi-arid gites

6 (12) Spp favouring woodlands on fine textured soils

7 (7) Saline

8 (2)

habitats

$9 \quad(2)$

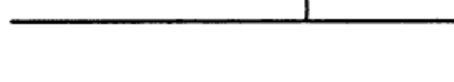

10 (5)

11 (4)

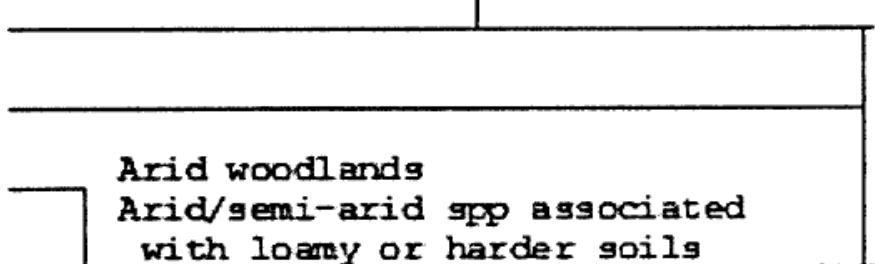

Generally low in landscape

Arid/semi-arid gpp agsociated

Various parts

of landscape

12 (23)

0.1

$0^{1} .20$

0.22

0.24

1

0.27

Fredominantly SW (megic or semi-arid)

distributions; gpp asgociated with

lower temperatures and higher rainfall (67) species)

Disgimilarity measure

Figure 8 Species groups derived by classifying the 122 vertebrate species on the basis of their presence/absence at the 252 quadrats not overtly affected by secondary salinity. Dendrogram structure shown to the 12 group level is displayed. Numbers of species for a given partition are shown in brackets. The text on the dendrogram describes the species in that part of the dendrogram, based on extrinsic information on these species (see Methods). 
the maximum temperature of the warmest period (Figure 9). A number of other attributes, almost all climatic, or having a high degree of correlation with climatic attributes, also showed significance (Table 5).

Within the south-western set (Groups 1 to 5) the final fusion brought Groups 1 to 3 (55 species) together with Groups 4 and 5 (12 species). Groups 1 to 3 comprised mesic or relatively widespread species occurring throughout the landscape (such as Menetia greyii) whereas Groups 4 and 5 comprised species with distributions centred on sandy, semiarid areas. The physical attribute with the highest significance was latitude (related to climatic variables). A number of other attributes were also highly significant, with climatic ones showing highest significance. A range of soil nutrient values and habitat attributes were significant.

At the fusion point below this, Groups 1 and 2 were joined with Group 3. Group 3 comprised 33 species that were mostly widespread in the study area and beyond, including species such as Mus domesticus, Menetia greyii and Pogona minor, which have relatively broad habitat preferences. Species in this group predominantly show distribution patterns centred on semi-arid areas. Some, including Cryptoblepharus plagiocephalus and Cercartetus concinnus, normally occur only in woodland, but are widespread within that broad habitat type. Most species in this group (e.g. Tarsipes rostratus, Limnodynastes dorsalis) show a preference for sandy surfaces, but many (e.g. Delma australis, Diplodactylus granariensis) occur also on finer textured soils.

Group 1 comprised 14 species with mesic distribution patterns. This group included seven of the 22 frog species encountered in the survey, plus six reptiles and one mammal. The frogs in this group were species that usually or always inhabit permanent or winter-wet swamps, usually on sandy substrates. Examples of other vertebrates in this group include the skink Acritoscincus trilineatum, which favours damp places in forests and woodlands, usually on sandy surfaces and the mammal Sminthopsis griseoventer, which favours relatively mesic woodlands.

The eight species in Group 2 (five reptiles, two mammals and one frog) display mesic and/or semiarid distributions. Where semi-arid, they tend to be near the south coast, in the south-eastern part of the study area. They include Rattus fuscipes, a mammal that prefers relatively moist, near coastal heaths, Litoria cyclorhyncha, a frog inhabiting near permanent swamps in the south-eastern part of the study area, and Ctenotus gemmula, a skink with a temperate semi-arid distribution, usually in heaths on white sands.

Group 4 comprised only five species - four

Table 5 Differences in physical attributes between the two groups at each higher order fusion point in the dendrogram resulting from the classification of species on the basis of their occurrence at the quadrats without secondary salinisation (ie quadrats with little or no salinity risk, or ones that are naturally saline) ( $\mathrm{n}=252$ ), using MannWhitney $U$ tests. Other significant attributes are listed in order of decreasing significance. Fusions involving a group with five or less species are omitted from the table.

\begin{tabular}{|c|c|c|c|c|}
\hline $\begin{array}{l}\text { Total } \\
\text { number of } \\
\text { groups at } \\
\text { this point }\end{array}$ & $\begin{array}{l}\text { Physical } \\
\text { attribute with } \\
\text { highest } \\
\text { significance }\end{array}$ & z value & $p$ & $\begin{array}{l}\text { Other significant attributes, in decreasing order } \\
\text { (only attributes with significance }<0.0001 \text { are listed) }\end{array}$ \\
\hline 2 & $M \times T_{-} W P$ & -6.33 & $<0.0001$ & $\begin{array}{l}\text { MTWrmQtr, Temp_AR, Isotherm, PrecAnnu, MTAnnual, Lat, } \\
\text { MTDiuRng, Silt, PrecWrmQ, Total_P, MTWetQtr, MTDryQtr, } \\
\text { PrecWetQ }\end{array}$ \\
\hline 3 & Lat & 5.36 & $<0.0001$ & $\begin{array}{l}\text { MTAnnual, MTWrmQtr, MTWetQtr, Long, MTDryQtr, OrgC, } \\
\text { Total_N, MxTWP, PrecSeas, Ex_K, Ex_Mg, Ex_Ca, logEC, K, Ex_Na, } \\
\text { MTDiuRng, TreeCanp, A_horizon, MnT_CP, Temp_AR, EC, } \\
\text { Total_P, HCS, Drainage, GrndStuf }\end{array}$ \\
\hline 4 & Dist_cst & -5.35 & $<0.0001$ & Isotherm, Elev \\
\hline 7 & Dist_cst & -5.91 & $<0.0001$ & $\begin{array}{l}\text { MTDiuRng, Temp_AR, MxTWP, MTWrmQtr, PrecWrmQ Isotherm, } \\
\text { MTDryQtr, Elev, HCS, Lat, MTAnnual, MnT_CP, PrecAnnu }\end{array}$ \\
\hline 9 & $\begin{array}{l}\text { TreeCanp, } \\
\text { adjSAL }\end{array}$ & 3.55 & $<0.0001$ & $\begin{array}{l}Z=+3.55: \text { TreeCanp, Isotherm, PrecAnnu } \\
Z=-3.55: \text { adiSAL, EC, MxT_WP, } \log E C, \text { TempAR, MTDiuRng }\end{array}$ \\
\hline 11 & Long & -3.75 & $<0.0001$ & \\
\hline 13 & Dist_cst & 3.21 & $<0.0001$ & \\
\hline 16 & $\begin{array}{l}\text { PrecAnnu }= \\
\text { Temp_AR }= \\
\text { PrecWetQ }= \\
\text { OrgC }\end{array}$ & 2.88 & $<0.0001$ & \\
\hline 22 & Isotherm & 4.75 & $<0.0001$ & MxT_WP, MTDiuRng, MTWrmQtr, PrecWrmQ MTDryQtr \\
\hline
\end{tabular}


(a)

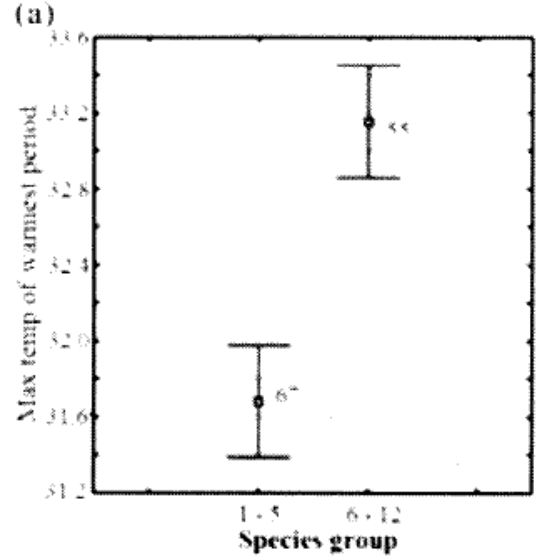

(c)

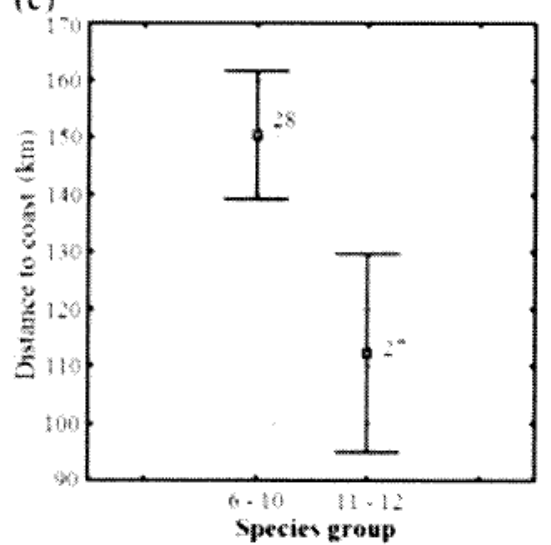

(e)

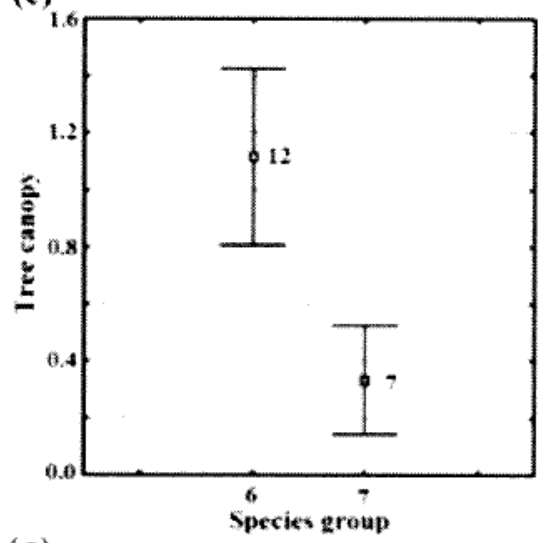

(g)

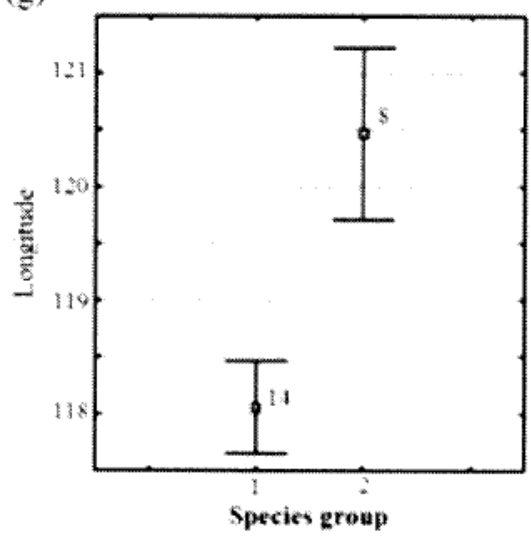

(b)

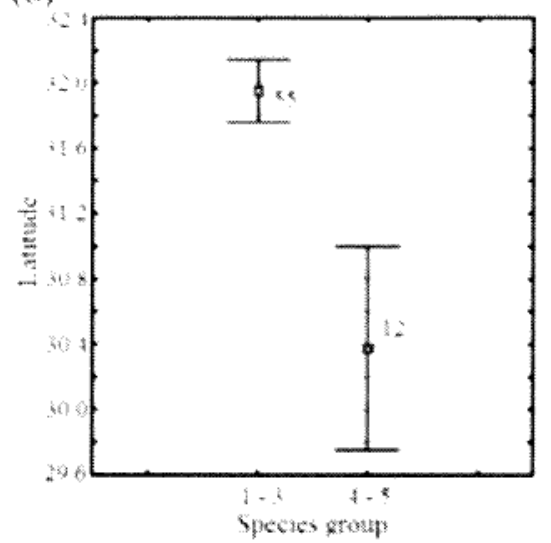

(d)

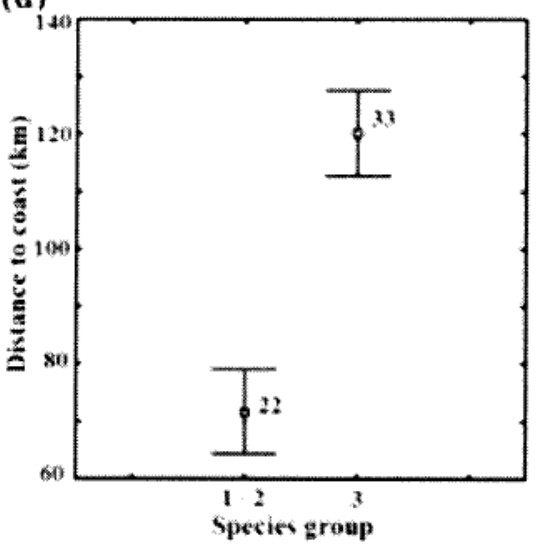

(f)

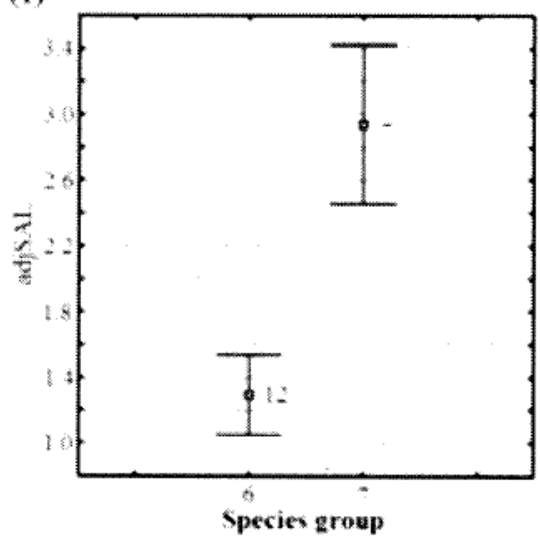

Figure 9 Comparison of attributes with the highest significance that were associated with the higher order fusion points of the species classification: (a) maximum temperature of the warmest period for the sets of quadrats occupied by each of the two species groups at the final fusion point (Groups 1-5 vs 6-12), (b) latitude for Groups 1-3 vs Groups 4-5, (c) distance to the coast for Groups 6-10 vs 11-12, (d) distance to the coast for Groups 1-2 vs Group 3, (e) tree canopy for Group 6 vs 7, (f) salinity class for Group 6 vs 7, (g) longitude for group 1 vs 2 . Mean and $95 \%$ confidence limits are shown; means are labelled with the number of species in that partition. Results of Mann-Whitney tests on these comparisons are given in Table 5. Other significant variables are also listed in Table 5. 
reptiles and one frog, all of which occurred infrequently in the data set. The reptiles were all species that occur on sandy Quaternary surfaces near the west coast. The frog (Pseudophryne occidentalis) occurred at only one site in this data set, but is otherwise known mostly from Quaternary sands and aggregates in semi-arid environments (e.g. McKenzie et al., 1993). Group 5 consisted of seven species, comprising six reptiles and one mammal, Pseudomys albocinereus. All are species inhabiting semi-arid areas and all are usually found on sandplains, although sometimes also on lateritic uplands. None of the physical attributes we measured showed significant differences at this fusion point.

Within the other side of the dendrogram (Groups 6 to 12) the final fusion was between Groups 6 to 10 , and Groups 11 and 12 . The 28 species in Groups 6 to 10 tended to occur relatively low in the landscape, with one subgroup consisting of species that show mesic distribution patterns, while the 27 species in Groups 11 and 12 comprise species that occur in various parts of the landscape. Distance to the coast was the attribute with the highest significance at this fusion point, with isothermality and elevation also being significant.

At most fusion points below this, there were few if any attributes with significance. Where there was significance (points 9, 13, 16 and 22; Table 5), significant attributes were climatic ones, or correlated with climatic gradients, except at fusion point 9, where salinity related attributes were predominant.

At fusion point 9 (joining Groups 6 and 7), both groups of species tend to occur relatively low in the landscape. Group 6 comprised 12 species including reptiles such as Ctenotus ?delli and Egernia richardi that prefer woodlands. Most species in this group prefer finer textured soils and at least two (Morethia adelaidensis and $M$. lineoocellata) sometimes occur in samphire or saltbush. Group 7 includes three mammals and four reptiles, most of which prefer finer textured soils. Ctenophorus salinarum and Sminthopsis crassicaudata prefer or tolerate saline areas. In our data set, the mammal S. crassicaudata occurred at 14 of the 16 naturally saline quadrats, plus at another 18 sites spread through the landscape, although more commonly in saline sites low in the landscape. The reptile $C t$. salinarum was found at six of the 16 naturally saline quadrats, plus at three other salinised sites, all on dissection valley floors.

Groups 8 and 9 included four species that occurred at only one or two quadrats. Three of these were Lerista species that only occur on the extreme margins of the study area. Group 10 consists of five reptile species, and Group 11 four reptile species with predominantly arid zone distributions. The species in Group 10 occur in our study area only in the northern extremity, and those in Group 11 only on the inland margin.

Group 12 comprises 23 species, most with broad habitat preferences, but with a preference for loamy or harder soils. Almost all have geographic ranges that are centred on the arid zone (e.g. Lerista muelleri, Varanus caudolineatus), or are widespread in arid and semi-arid areas (e.g. Morethia butleri, Eremiascincus richardsonii).

\section{DISCUSSION}

\section{Patterns of vertebrate species richness}

It is well known that species richness of small vertebrates (and other animals) is correlated with area sampled (e.g. Kitchener et al., 1980a, b; Kitchener and How, 1982; MacNally and Brown, 2001). However, where sampling area and effort is kept constant, and sampling is throughout the landscape at a regional scale as in the current study, a number of other attributes emerge as correlates of species richness. Interestingly, even though there are distinct temperature and rainfall gradients extending generally south-west to north-east through the study area, vertebrate species richness was correlated more highly with high levels of sand with low soil nutrient levels and good drainage. This may be partly for historical reasons - the landscape is an ancient one with low nutrient levels, and most species in the study area are presumably adapted to such conditions. In addition, many frogs, reptiles and mammals in the study area use burrows, and these would be easier to dig in sandy substrates.

However, when mammals, reptiles and frogs were considered separately, climatic attributes are also significant. In addition, species richness in each of these groups showed correlations with different physical attributes, presumably because their different physiological attributes and shelter requirements result in different responses to environmental gradients.

Taken separately, overall anuran species richness was correlated with deep, nutrient poor sands. No rainfall attributes showed significant correlations with species richness in the Limnodynastinae. All these species burrow, so they may escape the vagaries of irregular water supply. However, rainfall attributes did show significant correlations with species richness for the Myobatrachinae. These findings are slightly different from the pattern reported by Roberts (1993) who provided a map indicating a correlation between frog species richness and rainfall gradients in south-western Australia. However, this map was derived from broad species distribution patterns, based primarily on museum records, often sampled from breeding choruses, usually focussed on discrete wetlands, 
Figure 10 Data matrix re-ordered according to dendrograms (see text). Site codes printed vertically.

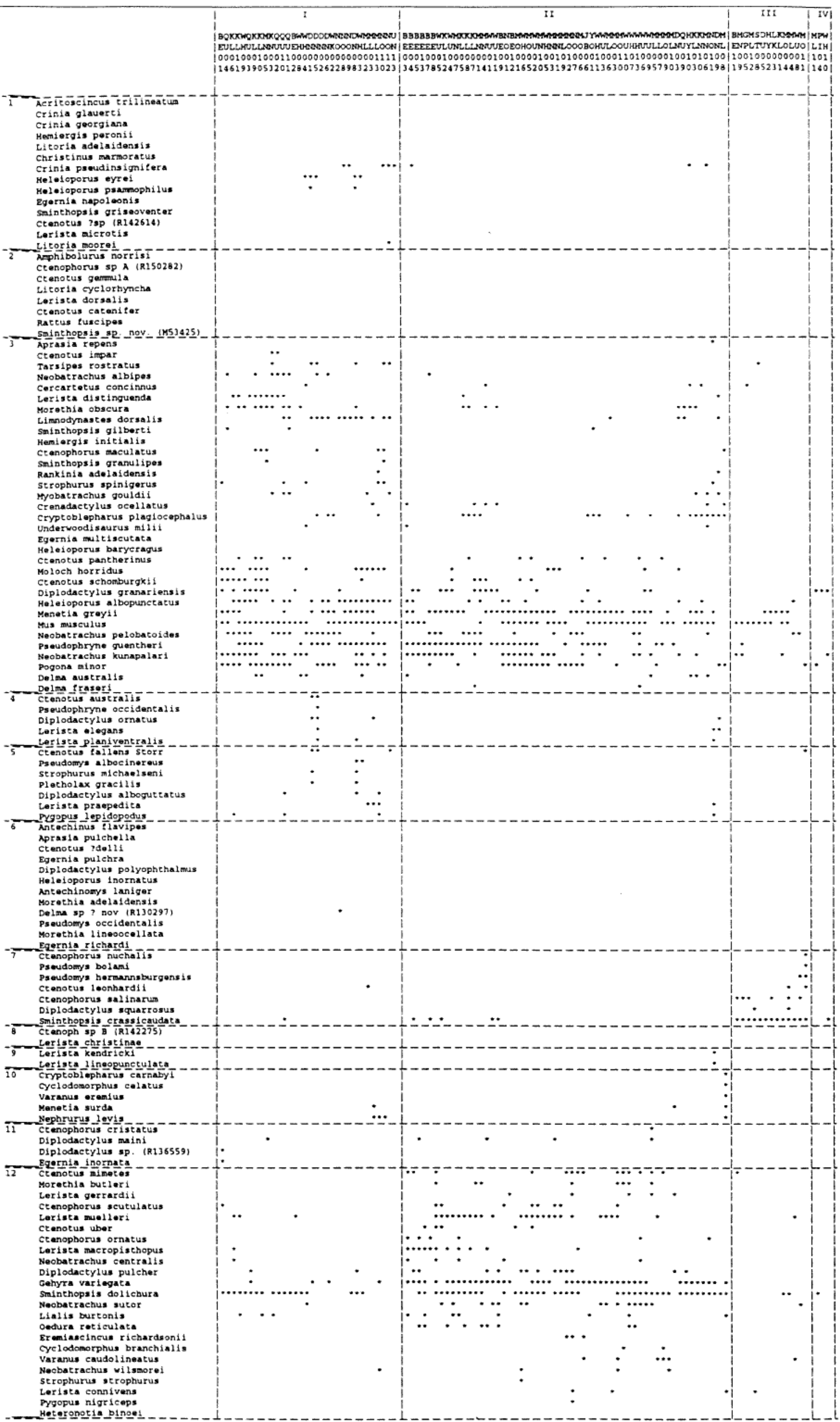




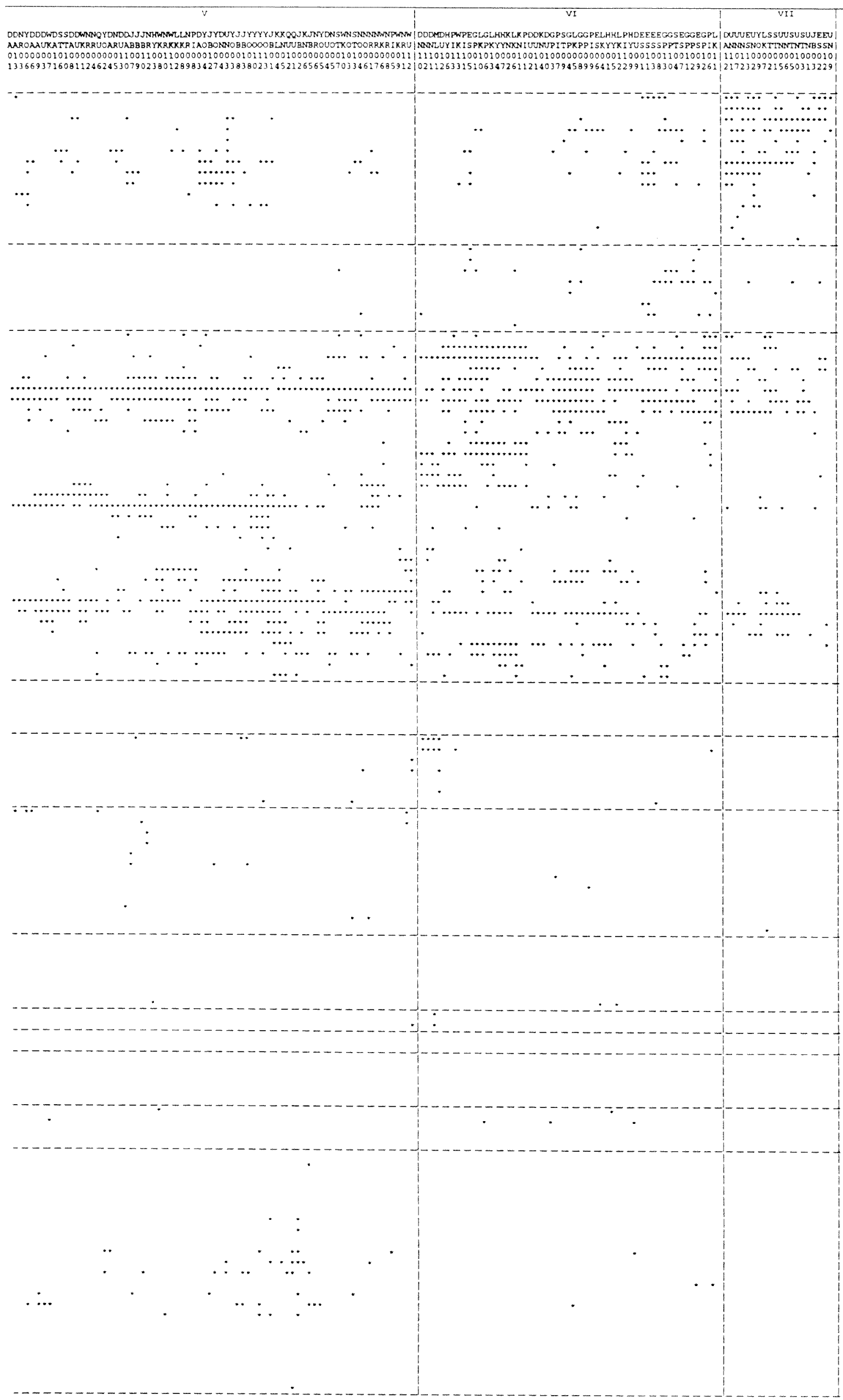


rather than from the whole landscape. It is interesting to note that, in the present study, frogs were found in many parts of the landscape, not just in wetlands. Nevertheless, the high concentrations of individual frogs at freshwater wetland sites, which tend to be low in the landscape and hence susceptible to secondary salinisation, is of some concern in conservation management.

The high significance levels associated with soil sandiness is likely to be a reflection of the high proportion of frog species that burrow. The land surface in south-western Australia is predominantly sandy or sandy loam (McArthur, 1993) and the region is particularly rich in burrowing frogs with $62 \%$ of the anuran fauna being burrowers (Tyler et al., 2000). Similar studies to ours appear not to have been done in temperate areas. However, this pattern of increasing species richness in relation to sands rather than rainfall is in contrast to the margin of the tropical savannas, where frog species richness increases with rainfall and is higher on clay than sandy quadrats, presumably because the clay quadrats have higher water availability (Woinarski et al., 1999), and/or because of the lower proportion of burrowers.

Reptile species richness was correlated with high temperatures, at high, well-drained positions in the landscape. Again, this is in contrast to the tropical savannas, where species richness is correlated primarily with rainfall (Woinarski et al., 1999). However, in temperate areas, ectothermic animals the size of most reptiles are likely to be more abundant at sites with higher annual amounts of sunshine, which occur at lower latitudes and/or high in the landscape. Mammal species richness was highest at quadrats with low habitat complexity scores and low nutrient levels, low winter rainfall and low winter temperatures, and high levels of sand. Reasons for this pattern are not clear.

Our results differ to some degree from those of studies where sampling is at a much coarser scale. For example, Pianka and Schall (1981), sampling in $240 \times 240 \mathrm{~km}$ grid squares and, with a reduced set of environmental attributes, found that, in Australia generally, the most important variable associated with frog species richness was annual precipitation, and for lizards and marsupials was annual hours of sunshine. Examination of the maps presented by Pianka and Schall (1981) suggests that these relationships would also hold for south-western Australia, except for marsupials. Similarly, from broad scale sampling, the species richness of agamid lizards (dragons) (Witten, 1982) and varanids (King and Green, 1993) increases along a gradient from south-western Australia into the arid zone, showing a negative correlation with rainfall. In our data set, species richness of dragons and geckos was positively correlated with temperature variables and negatively with rainfall, while skinks showed the opposite trend. Nevertheless, the scale and extent of sampling, as well as the nature of the variables measured, influence the conclusions that are drawn, and the uses to which the data can be put. For example, if we had extended the sampling of skinks further into the high rainfall areas of the south-west, it is likely that a more complex pattern would have emerged, including a declining species richness in some skink genera (e.g. Ctenotus). Our results are most appropriate for predicting likely species richness at a quadrat scale across the wheatbelt study area, and are therefore appropriate at a management scale, but may not hold at a coarser scale, or in the adjacent high rainfall zone to the south-west.

\section{Patterns of species composition}

These analyses revealed the presence of two distinct faunas in the Western Australian wheatbelt - one in the northern and north-western part of the study area, the other in the south and south-east. This division is associated with differences in climatic (temperature and rainfall) variables. Although we have not reported the details here, this is also the case when secondary saline quadrats are included in the analysis. Within each of these faunas, major divisions are associated with substrate type and vegetation attributes as well as climatic attributes. The second last fusion point in the dendrogram was between a set of sites with low salinity and another set, mostly from inland areas, that had high salinity. This suggests that salinity has been an important factor influencing biogeographic patterns, pre-dating European impacts on these systems. This is not surprising given that some of the saltflats in the study area date from about the Miocene (Salama, 1994). In addition to the age factor, it is likely that there have been multiple periods of salinisation in response to previous fluctuations in climate (Harper and Gilkes, 2004). Salinisation therefore may have had long standing effects not only on biogeographic patterns, but also on the nature of the biota in the Western Australian wheatbelt.

At the scale of the study area, rainfall and temperature attributes were highly significant in comparisons between dendrogram partition groups resulting from the classification analysis of quadrats or species. Substrate attributes were important at a local scale, but examination of the physical attributes showing significance at higher levels in the dendrograms (Figure 4, Table 4; Figure 8, Table 5) showed that some substrate attributes were also important at a relatively broad scale. Other features of the environment, not measured by us, may also be associated with the patterns we discerned. For example, the western zone of our study area has a rejuvenated drainage system that flows westwards, 
while the eastern zone's ancient drainage system comprises chains of salt lakes and follows Tertiary paleodrainage lines that are orientated northwards and/or eastwards (e.g. Beard, 2000). Such features of the landscape might also have significant biogeographical significance, but more detailed sampling would be needed to test such hypotheses.

Correlations between climatic and substrate variables could be discerned at low levels in the classification analysis, suggesting strong deterministic patterns in vertebrate species composition across the study area. This suggests that population and community processes operate across a broad scale, similar to the situation in some bird communities (Bennett et al., 2004). However, at finer scales, relationships with substrate are harder to characterise. This was also noted for vegetation in our study area by Dirnbock et al. (2002) who demonstrated that vegetation distribution showed significant responses to rainfall and subsequent topographically mediated water re-distribution, but these variables were insufficient to explain vegetation distribution effectively at the local scale.

Consideration of mammals, reptiles or anurans separately would be expected to reveal differences in patterning between these three groups (McKenzie et al., 2000b). However, for both quadrat and species classifications, interpretation was more difficult when mammals, reptiles or anurans were considered separately, and these analyses have not been reported here. The lack of clarity in these classifications could be because the number of species per quadrat for each of these groups was too low to allow meaningful patterning to be discerned, or because guild boundaries do not necessarily conform to taxonomic boundaries (Adams, 1985) and consideration of mammals, reptiles or frogs on their own provides an inadequate sample of the guilds occupied by these species. For frogs, there were only 2.7 species per quadrat. For mammals, there were only 16 species in the analysis, and an average of only 1.9 species per quadrat (or 1.3 ignoring the introduced Mus). The absence from the data set of those mammals ( $15 \%$ of the 'trappable' species) that are regionally extinct might also complicate interpretation of this subset. In addition, the introduced Mus was the dominant mammal in terms of the number of quadrats at which it occurred (164), and this might also complicate interpretation. Patterns shown by reptiles on their own were more similar to the combined vertebrate data set, presumably because reptiles constituted $70 \%$ of the species in the combined analysis. Cross taxon congruence is discussed further in McKenzie et al. (this volume).

Our interpretation of broad scale biogeographic patterns is broadly consistent with that of Kitchener et al. (1980a) who identified five groups of reptiles in the wheatbelt on the basis of common features in their geographic ranges. They identified two major groups, a widespread one and an inland one, plus three smaller groups with west coast, south-west coast or south-western distributions. Similarly, Storr (1964) and Chapman and Dell (1985), using knowledge of the geographic ranges of the component species of the wheatbelt herpetofauna, identified an arid zone element and a smaller mesotemperate element. With the benefit of finer scale sampling at many more sites, we have been able to confirm these general patterns, but show that there is a considerable degree of patterning within each of the two major groups. Earlier interpretations have been based on current distributional range and historical biogeographical analyses. The present study indicates that much of the patterning that can be discerned is related to physical attributes of the study area.

\section{Faunal change in the wheatbelt}

By selecting sites that were almost all on Crown reserves, with as little evidence of disturbance as possible, we attempted to discern assemblage patterns that may have been in place at the time of European colonisation. However, it is well known that many changes have occurred since that time. At the regional scale, there have been significant changes in the mammal fauna (Table 2; McKenzie et al., 2002) - there are 11 introduced species in the study area and 17 species of the pre-European total of 64 species are now extinct. While the losses are well known, the exact reasons for the onset of the observed declines are less clear (Kitchener et al., 1980b; Burbidge and McKenzie, 1989). Given that so many mammals have been lost from the wheatbelt as a whole, it is likely that there have been many local mammal extinctions, and such losses must have had an impact on our analyses. It is unclear what this impact may have been, but assuming that such losses have been relatively uniform or random across the study area, the impact on our conclusions has probably not been very great. Birds of the wheatbelt have also suffered to some degree - Saunders (1989) found that two out of 148 species of landbirds were regionally extinct, while varying numbers have become extinct at the level of district or remnant. In addition, there are at least seven introduced bird species in the Avon Wheatbelt bioregion alone (Barrett et al., 2003). On the other hand, there are no introduced frogs or reptiles in the area, and none of the original 24 frogs or 142 reptiles is extinct, suggesting that these faunas may be intact, at least at a regional scale, although it is likely that declines and some local extinctions have occurred in a variety of reptile groups including snakes (e.g. Aspidites ramsayi) and skinks (e.g. Egernia stokesii).

The number of reptile species per unit area in the wheatbelt may have declined already. The mean 
Table 6 Herpetofauna and mammal species richness from pitfall trap sampling at quadrats in various parts of southern Western Australia. Figures are mean numbers of species per quadrat with standard deviation, $\mathrm{n}$ (in brackets) is the number of quadrats. Data are only included for studies using similar sized quadrats with similar sampling intensity. All surveys covered a full range of landscape units and all quadrats were nonecotonal.

\begin{tabular}{|c|c|c|c|}
\hline Region & Herpetofauna & Mammals & Data source \\
\hline Carnarvon Basin & $16.3 \pm 5.6(63)$ & $2.8(63)$ & McKenzie et al. (2000a) \\
\hline Murchison/Coolgardie & $12.2 \pm 4.5(109)$ & $3.5 \pm 1.5(61)$ & $\begin{array}{l}\text { Burbidge et al. (1995); McKenzie et al. (1992, } \\
\text { 1993, 1994, 2000a); McKenzie and Rolfe (1995) }\end{array}$ \\
\hline Wheatbelt & $8.4 \pm 3.3(252)$ & $1.9 \pm 1.1(252)$ & This study \\
\hline Yanchep National Park & $13.0 \pm 2.7(10)$ & $1.7 \pm 0.5(10)$ & A.H. Burbidge and J.K. Rolfe unpubl. data \\
\hline Fitzgerald River National Park & $3.7 \pm 2.6(63)$ & $3.1 \pm 1.3(63)$ & Chapman and Newbey (1995) \\
\hline Cape Arid National Park & $9.4 \pm 2.7(15)$ & $2.8 \pm 0.9(15)$ & $\begin{array}{l}\text { A.H. Burbidge, J.K. Rolfe and } \\
\text { N.L. McKenzie unpubl. data }\end{array}$ \\
\hline
\end{tabular}

number of 'trappable' reptile species per quadrat on non-saline quadrats in the dissection valleys $(\mathrm{SAL}=1$ or 2 , landforms 3 to 7 ) was 5.8 (s.d. $=2.3$ ) and on the 'old plateau' 5.62 (s.d. = 2.2) but there are no pre-existing data to compare with. When all herpetofauna species are considered, we recorded an average of 8.4 (s.d $=3.3$ ) species per quadrat. This is lower than that reported from adjacent areas (Table 6), particularly in the nearby arid areas (Carnarvon, Murchison and Coolgardie bioregions). It is higher than in the 330000 ha Fitzgerald River National Park to the south of our study area (Table 6 ), but this park is coastal, cooler and wetter than any of the other areas and is mostly heathland, and has a limited range of habitats for reptiles. The number of mammal species we trapped per quadrat was within the range of richness figures reported for nearby areas. While quadrats in arid areas might be expected to have higher species richness of reptiles, it does seem that richness levels in the wheatbelt are low.

Much of the native vegetation in the wheatbelt has been cleared for agriculture (Saunders et al., 1985) and the resultant fragmentation of habitats may have impacted negatively on the levels of reptile species richness within our sample sites. Species of reptile may be lost from small remnants in agricultural areas (Smith et al., 1996, 1997; Driscoll, 2004). Sarre (1995) and Sarre et al. (1995) found that, amongst two similar sized geckos in the central wheatbelt, the habitat generalist Gehyra variegata showed a much higher persistence in small remnants than did the specialist Oedura reticulata, and $O$. reticulata appeared to have a lower dispersal ability. Sarre et al. (1995) predicted that the population genetic structure of $O$. reticulata would become fragmented and that populations would be lost from remnants more quickly than in $G$. variegata. Recent work by $M$. Hoehn (personal communication) has produced data consistent with this hypothesis. In this context, it should also be noted that presence in a remnant does not necessarily equate with persistence, as both these species are known to have a longevity in excess of 16 years in the Western Australian wheatbelt (R. How and J. Dell, personal communication) and so current measures of presence might be overestimates of persistence (the 'storage effect' discussed by Warner and Chesson (1985)). Similar effects may be occurring in other reptiles. For example, the skinks Egernia richardi (preferring woodlands with hollows or decorticating bark) and E. stokesii (preferring scrubs and woodlands with logs and bark) have distinct habitat preferences but, despite being relatively widespread, are poorly represented in our data set, and so may already have been lost from some sites through similar processes to those operating in Oedura. Similarly, How and Dell (1994) found that, on the nearby Swan Coastal Plain, some species such as Lerista elegans and Menetia greyii are relatively resistant to land use change while others such as Cyclodomorphus branchialis seem to be relatively susceptible to the effects of fragmentation. Nevertheless, they concluded that there was a relatively large group of lizards that can persist on small and modified patches of native vegetation, suggesting that the patches sampled in our data set might be relatively intact still. Even if the reptile fauna is currently relatively intact, it seems likely that fragmentation effects will erode the species richness of at least the smaller patches (Driscoll, 2004), although the actual process may be difficult to predict for individual species and patches (e.g. Englund and Hamback, 2004).

Another factor that may impact negatively on populations, or even persistence, of smaller reptiles is the introduced House Mouse. Mus was widespread at the time of our sampling, being found in 205 of the 304 quadrats sampled. It is known to occur in plagues, especially in agricultural areas. Mus is omnivorous and will eat invertebrates, sometimes in significant numbers (Watts and Aslin, 1981; Singleton and Krebs, in press; G. Singleton, personal communication). Newman (1993, 1994) and Pickard (1984, cited in 
Newman, 1994) recorded Mus eating skinks, and declines in populations of the skink Cyclodina macgregori and the gecko Hoplodactylus maculatus coincided with an increase in mouse numbers on Mana Island, New Zealand, following changes in agricultural practices. After the Mana mice were eradicated in 1989, the numbers of C. macgregrori recovered to the same levels, and $H$. maculatus increased to higher levels than previously recorded. This suggests that Mus could have significant impacts on assemblages of small ground-dwelling vertebrates and invertebrates in agricultural areas across southern Australia, both as a competitor and a predator, particularly when food sources in wheat paddocks decline and the surviving mice move into nearby native vegetation in search of food. They are potential competitors for both granivores and insectivores, as well as being potential predators (Cuthbert and Hilton, 2004). The possible impact of Mus on small ground-dwelling vertebrate assemblages deserves further investigation. In the wheatbelt, this might involve an analysis in which population sizes of Mus and other small vertebrates, patch size, distance to nearest paddock and time since clearing are investigated. Given that any effects of Mus on small vertebrates will occur in the context of additional predation by the introduced fox and cat, any analysis will also need to consider such effects. Impacts of Mus are likely to be less in larger reserves, but it is unknown how big a reserve would need to be to protect the small ground-dwelling vertebrate fauna from invading mice. This suggests that, when considering CAR (com-prehensiveness, adequacy and representativeness) characteristics of the wheatbelt reserve system, small reserves, with no buffering effects, are not likely to contribute to adequacy considerations in relation to small vertebrates.

In the face of the above known and suspected changes, it is relevant to ask whether changes in the vertebrate fauna caused through salinisation can be reversed. Views on whether salinisation can be reversed are generally pessimistic (see Hatton and Nulsen, 1999) although Harper and Gilkes (2004) suggest that salinisation is reversible, albeit over millennia. It remains to be seen whether the process of desalinisation can be accelerated with new agricultural systems that use more water. The issue for conservation is that the rapid process of salinisation in a fragmented landscape is not likely to allow the current flora and fauna to adapt or migrate. Although the biota appears to have evolved in relation to cycles of salinisation and subsequent recovery of the valley floors through geological time (Harper and Gilkes, 2004), it is unlikely to be able to withstand current processes unless they are reversed more rapidly than currently seems feasible.

\section{Conclusions}

There are two major vertebrate faunas in the wheatbelt: a northern fauna concentrated in the semi-arid northern and inland parts of the study area, and a southern/south-eastern fauna concentrated in the more mesic south and southeast. There are a number of recognisable groups within this overall dichotomy, including a small set of species centred on saline sites. These species clusters showed patterns consistent with the physical and climatic attributes of the quadrats where they occurred. Effects of salinity are superimposed on broad-scale patterning that is related to climate and, at a finer scale, to substrate. Salinisation appears to have had long standing effects on biogeographic patterns in the Western Australian wheatbelt. Relationships between species composition and climate and substrate could be discerned at low levels in the classification, suggesting strong deterministic relationships across the study area. Overall species richness was related to substrate, but when mammals, reptiles and frogs were considered separately, climatic attributes also emerged as being significant.

Results of this study have several implications for conservation management. For example, when it comes to management decisions at a local scale, it is important to consider management of each site, location or reserve in its biogeographic context. At the species level, our conclusions are consistent with those of McKenzie et al. (2003), who concluded that a few species are restricted to saline sites, but a diverse array of species occupies non-saline sites. Those species preferring valley floors and lower slopes will be disadvantaged by extensive salinisation in fragmented habitat, and these species may require particular attention in relation to reserve acquisition and management. Results of the present study suggest that some species may also be negatively impacted on during Mus invasions, perhaps to the extent that small reserves cannot provide them with an adequate level of protection. A further interesting finding was that frogs were found throughout the landscape, not just in wetlands, suggesting that connectivity between remnants may be more important for these species than previously recognised. These considerations lead us to agree with George et al. (1995) that integrated management programs over entire catchments will be necessary in order to maintain agricultural productivity as well as conservation values. Nevertheless, there is doubt that the impacts of salinisation and fragmentation can be mitigated quickly enough to allow the small, ground-dwelling vertebrate fauna to withstand the effects of these processes in the Western Australian wheatbelt 


\section{ACKNOWLEDGEMENTS}

We thank M.A. Cowan, N. Hall, P.F. van Heurck, W.P. Muir and L.A. Smith for assistance in establishing trap lines and/or field sampling, P. de Tores and $\mathrm{M}$. Hillier for advice on calculation of distance to the coast, T.C. Stoneman for the soil salinity assignments, L.A. Smith for assistance with specimen identification, P. Gioia who generated the climatic data-set using the computer package ANUCLIM, and the Chemistry Centre (Western Australia) for carrying out soil chemical analyses. Thanks also to G. Singleton, C. Krebs, G. Saunders and $\mathrm{E}$. Murphy for alerting us to critical references in relation to $M u s$ biology, and $\mathrm{M}$. and L. Brooker for bringing pertinent literature references to our attention. Useful and constructive comments on earlier drafts of this manuscript were provided by P. Doughty, A. Fisher, L. Gibson, D. Pearson and J. Richardson. Funding for this study was provided as part of the State Salinity Strategy.

\section{REFERENCES}

Adams, J. (1985). The definition and interpretation of guild structure in ecological communities. Journal of Animal Ecology 54: 43-59.

ANZECC (2001). Implications of salinity for biodiversity conservation and management. Australian and New Zealand Environment and Conservation Council, Canberra.

Aplin, K.P. and Smith, L.A. (2001). Checklist of the frogs and reptiles of Western Australia. Records of the Western Australian Museum Supplement 63: 51-74.

Austin, M.P. (1991). Vegetation theory in relation to costefficient survey. In C.R. Margules and M.P. Austin (eds), Nature conservation: cost effective biological surveys and data analysis: 17-22. CSIRO, Canberra.

Austin, M.P. and McKenzie, N.J. (1988). Data analysis. In R.H. Gunn, J.A. Beattie, R.E. Reid and R.H.M. van der Graaff (eds), Australian soil and land survey handbook: guidelines for conducting surveys: 210-232. Inkata Press, Melbourne.

Barrett, G., Silcocks, A., Barry, S., Cunningham, R. and Poulter, R. (2003). The new atlas of australian birds. Royal Australasian Ornithologists Union, Melbourne.

Beard, J.S. (1990). Plant life of Western Australia. Kangaroo Press, Kenhurst, NSW.

Beard, J.S. (2000). Drainage evolution in the Moore Monger system, Western Australia. Journal of the Royal Society of Western Australia 83: 29-38.

Belbin, L. (1980). TWOSTEP: a program incorporating asymmetric comparisons that uses two steps to produce a dissimilarity matrix. Division of Land Use Research Technical Memorandum 80/9. CSIRO, Canberra.

Belbin, L. (1991). The analysis of pattern in bio-survey data. In C. R. Margules and M. P. Austin (eds), Nature conservation: cost effective biological surveys and data analysis: 176-190. CSIRO, Melbourne.
Belbin, L. (1995). PATN technical reference. CSIRO, Canberra

Bennett, A.F., Hinsley, S.A., Bellamy, P.E., Swetnam, R.D. and MacNally, R. (2004) Do regional gradients in land-use influence richness, composition and turnover of bird assemblages in small woods? Biological Conservation 119: 191-206.

Beresford, Q., Bekle, H., Phillips, H. and Mulcock, J. (2001). The salinity crisis. Landscape, communities and politics. University of Western Australia Press, Perth.

Bettenay, E. and Hingston, F.J. (1964). Development and distribution of soils of the Merredin area, Western Australia. Australian Journal of Soil Research 2: 173186.

Briggs, S.V. and Taws, N. (2003). Impacts of salinity on biodiversity - clear understanding or muddy confusion? Australian Journal of Botany 51: 609-617.

Burbidge, A.A. and McKenzie, N.L. (1989). Patterns in the modern decline of Western Australia's vertebrate fauna: causes and conservation implications. Biological Conservation 50: 143-198.

Burbidge, A.A., Fuller, P.J. and McKenzie, N.L. (1995). Vertebrate fauna. Records of the Western Australian Museum Supplement 49: 208-245.

Bureau of Meteorology (2001). What is the weather usually like? Climate averages for Australian sites: averages for Western Australian sites. Bureau of Meteorology, Perth

Chapman, A. and Dell, J. (1985). Biology and zoogeography of the amphibians and reptiles of the Western Australian wheatbelt. Records of the Western Australian Museum 12: 1-46.

Chapman, A. and Newbey, K. (1995). A biological survey of the Fitzgerald area, Western Australia. CALMScience Supplement 3: 1-258.

Clarke, C.J., George, R.J., Bell, R.W. and Hatton, T.J. (2002). Dryland salinity in south-western Australia: its origins, remedies, and future research directions. Australian Journal of Soil Research 40: 93-113.

Cody, M.L. (1986). Diversity, rarity, and conservation in Mediterranean-climate regions. In M.E. Soule (ed.), Conservation Biology. The science of scarcity and diversity: 122-152. Sinauer, Massachusetts.

Cramer, V. and Hobbs, R.J. (2002). Ecological consequences of altered hydrological regimes in fragmented ecosystems in southern Australia: impacts and possible management responses. Austral Ecology 27: 546-564.

Cuthbert, R. and Hilton, G. (2004). Introduced house mice Mus musculus: a significant predator of threatened and endemic birds on Gough Island, South Atlantic Ocean? Biological Conservation 117: 483489.

Czekanowski, J. (1932). Coefficient of racial likeness, und durchschnittliche differenz. Anthropologischer Anzeiger 9: $227--249$

Driscoll, D.A. (2004). Extinction and outbreaks accompany fragmentation of a reptile community. Ecological Applications 14: 220-240.

Ehmann, H. (1992). Encyclopedia of Australian animals. Reptiles. Angus and Robertson, Sydney. 
Englund, G. and Hamback, P.A. (2004). Scale dependence of emigration rates. Ecology 85: 320 - 327 .

Faith, D.P., Minchin, P.R. and Belbin, L. (1987). Compositional dissimilarity as a robust measure of ecological distance. Vegetatio 69: 57-68.

Ferdowsian, R., George, R., Lewis, F., McFarlane, D., Short, R. and Speed, R. (1996). The extent of dryland salinity in Western Australia. In $4^{\text {th }}$ National Conference and Workshop on the Productive Use and Rehabilitation of Saline Lands. Albany Western Australia 25-30 March 1996: 89-97. Promaco Conventions, Perth.

George, R.J., McFarlane, D.J. and Speed, R.J. (1995). The consequences of a changing hydrologic environment for native vegetation in southwestern Australia. In D.A. Saunders, J.I. Craig and E.M. Mattiske (eds), Nature Conservation 4: The Role of Networks: 9-22. Surrey Beatty, Sydney.

Ghassemi, F., Jakeman, A. J. and Nix, H. A. (1995). Salinisation of land and water resources. Human causes, extent, management and case studies. University of New South Wales Press, Sydney.

Harper, R.J. and Gilkes, R.J. (2004). Aeolian influences on the soils and landforms of the southern Yilgarn Craton of semi-arid, southwestern Australia. Geomorphology 59: 215-235.

Hatton, T.J. and Nulsen, R.A. (1999). Towards achieving functional ecosystem mimicry with respect to water cycling in southern Australian agriculture. Agroforestry Systems 45: 203-214.

Hingston, F.J. and Gailitis, V. (1976). The geographic variation of salt precipitated over Western Australia. Australian Journal of Soil Research 14: 319-335.

How, R.A., Cooper, N.K. and Bannister, J.L. (2001). Checklist of the mammals of Western Australia. Records of the Western Australian Museum Supplement 63: 91-98

How, R.A. and Dell, J. (1994). The zoogeographic significance of urban bushland remnants to reptiles in the Perth region, Western Australia. Pacific Conservation Biology 1: 132-140.

How, R.A., Dell, J. and Muir, B.G. (1988). Vertebrate fauna. In R.A. How and K.R. Newbey (eds), The biological survey of the eastern goldfields of Western Australia. Part 4: Lake Johnston-Hyden study area. Records of the Western Australian Museum Supplement 30: 44-83

King, D. and Green, B. (1993). Family Varanidae. In C.J. Glasby, G.J.B. Ross and P.L. Beesley (eds), Fauna of Australia. Vol. 2A. Amphibia and Reptilia: 253-260. Australian Government Publishing Service, Canberra.

Kitchener, D.J, Chapman, A., Dell, J. Muir, B.G. and Palmer, M. (1980a). Lizard assemblage and reserve size and structure in the Western Australian wheatbelt - some implications for conservation. Biological Conservation 17: 25-62.

Kitchener, D.J., Chapman, A., Muir, B.G. and Palmer, M. (1980b). The conservation value for mammals of reserves in the Western Australian wheatbelt. Biological Conservation 18: 179-207.

Kitchener, D.J. and How, R.A. (1982). Lizard species in small mainland habitat isolates and islands off southwestern Western Australia. Australian Wildlife Research 9: 357-363

MacNally, R. and Brown, G.W. (2001). Reptiles and habitat fragmentation in the box-ironbark forests of central Victoria, Australia: predictions, compositional change and faunal nestedness. Oecologia 128: 116-125.

Mann, E.A. (1907). Does clearing increase salt in ground. Journal of Agriculture Western Australia 15: 193.

McArthur, W.M. (1993). History of landscape development. In R.J. Hobbs and D.A. Saunders (eds), Reintegrating fragmented landscapes: towards sustainable production and nature conservation: 10-22. SpringerVerlag, New York.

McKenzie, N.L., Belbin, L, Margules, C.R. and Keighery, G.J. (1989). Selecting representative reserve systems in remote areas: a case study in the Nullarbor region, Australia. Biological Conservation 50: 239-261.

McKenzie, N.L., Rolfe, J.K. and Youngson, W.K. (1992). Vertebrate fauna. Records of the Western Australian Museum Supplement 41: 37-64.

McKenzie, N.L., Rolfe, J.K. and Youngson, W.K. (1995). Vertebrate fauna. Records of the Western Australian Museum Supplement 47: 51-85.

McKenzie, N.L., Rolfe, J.K., Hall, N.J. and Youngson, W.K. (1993). Vertebrate fauna. Records of the Western Australian Museum Supplement 42: 33-54.

McKenzie, N.L. and Rolfe, J.K. (1995). Vertebrate fauna. Records of the Western Australian Museum Supplement 49: $31-65$

McKenzie, N.L., Rolfe, J.K., Aplin, K.P., Cowan, M.A. and Smith, L.A. (2000a). Herpetofauna of the southern Carnarvon Basin, Western Australia. Records of the Western Australian Museum Supplement 61: 335-360.

McKenzie, N.L., Keighery, G.J., Gibson, N. and Rolfe, J.K. (2000b). Patterns in the biodiversity of terrestrial environments in the southern Carnarvon Basin, Western Australia. Records of the Western Australian Museum Supplement 61: 511-546.

McKenzie, N.L. (2000c). Non-volant mammals of the southern Carnarvon Basin, Western Australia. Records of the Western Australian Museum Supplement 61: 479510 .

McKenzie, N.L., Burbidge, A.A., Baynes, A., Brereton, R., Gordon, G., Menkhorst, P., Metcalfe, J., Robinson, A.C. and Woinarski, J.C.Z. (2002). Mammals. In P. Sattler, C. Creighton, R. Lawson and J. Tait (eds), Australian terrestrial biodiversity assessment 2002. National Land and Water Resources Audit, Canberra.

McKenzie, N.L., Burbidge, A.H. and Rolfe, J.K. (2003). Effect of salinity on small, ground-dwelling animals in the Western Australian wheatbelt. Australian Journal of Botany 51: 725-740.

McKenzie, N.L., Gibson, N., Keighery, G.J. and Rolfe, J.K. (this volume). Patterns in the biodiversity of terrestrial environments in the Western Australian wheatbelt. Records of the Western Australian Museum Supplement 67: 293-335.

McMahon, J.P., Hutchinson, M.F., Nix, H.A. and Ord, K.D. (1995). ANUCLLM users guide, version 1. Centre 
for Resource and Environmental Studies, Australian National University, Canberra.

Moseby, K.E. and Read, J.L. (2001). Factors affecting pitfall capture rates of small ground vertebrates in arid South Australia. II. Optimum pitfall trapping effort. Wildlife Research 28: 61-71.

Mulcahy, M.J. and Hingston, F.H. (1962). The development and distribution of the soils of the YorkQuairading area, Western Australia, in relation to landscape evaluation. Soil Publication 17. CSIRO, Melbourne.

Newman, D. (1993). Species as indicators: the fall and rise of McGregor's Skink, Mana Island. Ecological Management 1: 35-38.

Newman, D.G. (1994). Effects of a mouse, Mus musculus, eradication programme and habitat change on lizard populations of Mana Island, New Zealand, with special reference to McGregor's Skink, Cyclodina macgregori. New Zealand Journal of Zoology 21: 443-456.

Newsome, A.E. and Catling, P.C. (1979). Habitat preferences of mammals inhabiting heathlands of warm temperate coastal, montane and alpine regions of southeastern Australia. In R.L. Specht (ed.), Ecosystems of the world. Vol. 9A. Heathlands and related shrublands of the zoorld: 301-316. Elsevier, Amsterdam.

Pianka, E.R. and Schall, J.J. (1981). Species densities of Australian vertebrates. In A. Keast (ed.), Ecological biogeography of Australia: 1675-1694. Dr W. Junk, The Hague.

Pickard, C.R. (1984). The population ecology of the house mouse (Mus musculus) on Mana Island. Unpublished M.Sc. thesis, Victoria University, Wellington, N.Z.

Read, J.L. and Moseby, K.E. (2001). Factors affecting pitfall capture rates of small ground vertebrates in arid South Australia. I. The influence of weather and moon phase on capture rates of reptiles. Wildlife Research 28: 53-60.

Roberts, J.D. (1993). Natural history of the Anura. In C.J. Glasby, G.J.B. Ross and P.L. Beesley (eds), Fauna of Australia. Vol. 2A. Amphibia and Reptilia: 28-34. Australian Government Publishing Service, Canberra.

Rolfe, J.K. and McKenzie, N.L. (2000). Comparison of methods used to capture herpetofauna: an example from the Carnarvon Basin. Records of the Western Australian Museum Supplement 61: 361-370.

Salama, R.B. (1994) The evolution of saline lakes in the relict drainage of the Yilgarn River, Western Australia. In R.W. Renaut and W.M. Last (eds), Sedimentology and Geochemistry of Modern and Ancient Saline Lakes. SEPM Special Publication 50: 189-199. Society for Sedimentary Geology, Tulsa, Oklahoma.

Sarre, S. (1995). Size and structure of populations of Oedura reticulata (Reptilia: Gekkonidae) in woodland remnants: implications for the future regional distribution of a currently common species. Australian Journal of Ecology 20: 288-298.

Sarre, S., Smith, G.T. and Meyers, J.A. (1995) Persistence of two species of gecko (Oedura reticulata and Gehyra variegata) in remnant habitat. Biological Conservation 71: $25-33$.

Saunders, D.A. (1989). Changes in the avifauna of a region, district and remnant as a result of fragmentation of native vegetation: the wheatbelt of Western Australia. A case study. Biological Conservation 50: 99-135.

Saunders, D.A., Rowley, I. and Smith, G.T. (1985). The effects of clearing for agriculture on the distribution of cockatoos in the southwest of Western Australia. In A. Keast et al. (eds), Birds of eucalypt forests and woodlands: ecology, conseruation, management: 309-321. Surrey Beatty, Sydney.

Sexton, M. (2003). Silent flood - Australia's salinity crisis. ABC Books, Sydney.

Singleton, G.R. and Krebs, C.J. (in press) The secret world of wild mice. In The mouse in biomedical research.

Smith, G.T., Arnold, G.W., Sarre, S., Abensperg-Traun, M. and Steven, D.E. (1996). The effect of habitat fragmentation and livestock grazing on animal communities in remnants of Gimlet Eucalyptus salubris woodland in the Western Australian wheatbelt. II. Lizards. Journal of Applied Ecology 33: 1302-1310.

Smith, G.T., Leone, J. and Dickman, C.R. (1997). Small terrestrial vertebrate communities in remnant vegetation in the central wheatbelt of Western Australia. Western Australian Naturalist 21: 235-249.

Sneath, P.H.A. and Sokal, R.R. (1973). Numerical taxonomy. The principals and practice of numerical classification. W.H. Freeman, San Francisco.

Storr, G.M. (1964). Some aspects of the geography of Australian reptiles. Senckenbergiana Biologica 45: 577589.

Storr, G.M., Smith, L.A. and Johnstone, R.E. (1983). Lizards of Western Australia. II. Dragons and monitors. Western Australian Museum, Perth.

Storr, G.M., Smith, L.A. and Johnstone, R.E. (1990). Lizards of Western Australia. III. Geckos and pygopods. Western Australian Museum, Perth.

Storr, G.M., Smith, L.A. and Johnstone, R.E. (1999). Lizards of Western Australia. I. Skinks. Western Australian Museum, Perth.

Storr, G.M., Smith, L.A. and Johnstone, R.E. (2002). Snakes of Western Australia. Western Australian Museum, Perth.

Taylor, J.A. and Friend, G.R. (1984). Sampling strategies for fauna surveys. In K. Myers, C.R. Margules and I Musto (eds), Survey methods for nature conservation: 179-192. CSIRO, Canberra.

Thackway, R. and Creswell, I.D. (Eds) (1995). An interim biogeographic regionalisation for Australia: a framework for setting priorities in the National Reserves System Cooperative Program, version 4.0. Australian Nature Conservation Agency, Canberra.

Tyler, M.J., Smith, L.A. and Johnstone, R.E. (2000). Frogs of Western Australia. Western Australian Museum, Perth.

van Gool, D. and Moore, G. (1999). Land evaluation standards for land resource mapping, 2nd edn. Resource Management Technical Report 181. Agriculture Western Australia, Perth.

Watts, C.H.S. and Aslin, H.J. (1981). The Rodents of Australia. Angus and Robertson, Sydney. 
Warner, R.R. and Chesson, P.L. (1985). Coexistence mediated by recruitment fluctuations: a field guide to the storage effect. American Naturalist 125: 769-787.

Witten, G.J. (1982) Phyletic groups within the family Agamidae (Reptilia: Lacertilia) in Australia. In W.R. Barker and P.J.M. Greenslade (eds), Evolution of the flora and fauna of arid Australia: 225-228. Peacock Publications, Frewville, South Australia.
Woinarski, I.C.Z., Fisher, A. and Milne, D. (1999) Distribution patterns of vertebrates in relation to an extensive rainfall gradient and variation in soil texture in the tropical savannas of the Northern Territory, Australia. Journal of Tropical Ecology 15: 381 398.

Wood, W.E. (1924). Increase of salt in soil and streams following the destruction of the native vegetation. Journal of the Royal Society of Western Australia 10: 35 47. 